\title{
La religiosidad popular en la España del siglo xVIII: cofradías, ermitas y romerías*
}

\author{
Inmaculada Arias de Saavedra Alías \\ Universidad de Granada
}

\section{Introducción}

Durante el siglo XVIII se fueron configurando en la sociedad española dos formas distintas de entender la religión. Una religiosidad que podemos calificar de ilustrada, minoritaria e intelectualizada, propia de las élites más cultas y de los sectores más dinámicos de la jerarquía eclesiástica, bastante personalizada e intimista, poco preocupada por las manifestaciones exteriores, basada en actitudes personales profundas, con un grado de compromiso y exigencia alto y con una rigurosa concepción de la moral, y la religiosidad que se puede llamar popular $^{1}$, muy ligada al mundo de los sentimientos, apegada a la tradición y a las prácticas rituales externas, amiga de los actos de culto grandilocuentes, sin grandes planteamientos doctrinales ni teológicos, que respondía a las necesidades de las gentes sencillas, acompañándolas en los momentos más trascendentales del ciclo vital, proporcionándoles apoyo y consuelo en los momentos

\footnotetext{
* Conferencia pronunciada en Llanes el 12 de julio de 1999, dentro del curso Artes y culturas populares en la España del siglo XVIII, organizado por el Instituto Feijoo de Estudios del Siglo XVIII de la Universidad de Oviedo.

${ }^{1}$ Una visión de conjunto de la religiosidad de la época en Antonio Mestre Sanchís, «Religión y cultura en el siglo XVIII español», en La Iglesia en la España de los siglos XVII y XVII, vol. IV de Historia de la Iglesia de España, dirigida por Ricardo García Villoslada, Madrid, 1979, págs. 583-743 y Teófanes Egido López, «La religiosidad de los ilustrados», en La época de la Ilustración, I, vol. XXXI de Historia de España, Madrid, 1987, págs. 396-437; del mismo autor: «La religiosidad de los españoles (siglo xvIII), en Coloquio Internacional de Carlos III y su siglo, Madrid, 1990, vol. I, págs. 767-790.
} 
difíciles y al mismo tiempo cauces y oportunidades para desarrollar sus ansias de sociabilidad a través de fiestas y ritos que jalonaban con su repetitivo ritmo estacional la vida en la época del Antiguo Régimen.

El divorcio entre ambas formas de religiosidad parece claro, sobre todo en la segunda mitad del siglo XVIII. Los ilustrados consideraban algunas manifestaciones de la religiosidad popular como excesos, rayanos en la superstición, que habría que eliminar o al menos encauzar. Por ello durante esta etapa tuvo lugar una importante actividad represora, por parte de las autoridades eclesiásticas y civiles, sobre algunas de las manifestaciones de dicha religiosidad popular.

Una de las expresiones más importantes y generalizadas de la religiosidad popular eran, sin duda, las cofradías, comunidades de laicos en el seno de la Iglesia católica, que constituían el cauce asociativo más generalizado durante la Edad Moderna.

Las cofradías tienen su origen en la Edad Media². A partir del siglo XVI se multiplicaron por doquier, no sólo a través de la creación de nuevas fundaciones, sino también por medio de la restauración de antiguas hermandades de origen medieval, en un preludio de la gran eclosión cofradiera barroca, que se extendería a lo largo del siguiente siglo y tendría su punto culminante en la primera mitad del siglo xvIII, etapa en la que el ritmo fundacional de cofradías alcanzó su mayor velocidad ${ }^{3}$.

Aunque las cofradías tenían una indiscutible base popular, no se limitaban exclusivamente a estos grupos sociales. La realidad cofrade estaba totalmente incardinada en el conjunto de la sociedad, como muestra la existencia de hermandades nobiliarias, clericales y grupales de muy diversa índole. Actuar contra ellas y reprimir sus excesos era una tarea difícil y arriesgada, dada su indiscutible base popular y la protección que gozaban por parte de la Iglesia. Ciertos sectores del clero, especialmente los más doctos, eran críticos con diversas manifestaciones rayanas en la superstición y el fanatismo ${ }^{4}$, pero en general

\footnotetext{
${ }^{2}$ Antonio Rumeu de Armas, Historia de la previsión social en España, Madrid, 1944 (ed. facsímil en Barcelona, 1981), págs. 39-159.

${ }^{3}$ El proceso es bien conocido en el caso de la diócesis de Granada (Miguel Luis López Muñoz, «Implantación de las cofradías en la diócesis de Granada durante la Edad Moderna», en Actas del Congreso de Religiosidad Popular en Andalucía, Cabra, 1994, págs. 115-116).

${ }^{4}$ Sirva de ejemplo el padre Isla, en cuya novela se contienen críticas demoledoras a algunos aspectos de la religiosidad popular y en concreto de las cofradías: «En estas mayordomías de mis pecados se sirve poco a los santos y mucho a los cofrades. Y si no, dígame su reverencia, ¿se servirá mucho a los santos en que un probe como yo gaste en cada una de estas mayordomías sesenta reales en vino, veinte en tortada, diez en avellanas, para dar caridad a los cofrades, sin contar la cera, ni la comida a los señores sacerdotes ni la limosna del padre predicador, que todo junto hace subir la roncha a más de ciento y veinte reales?» (José Francisco de Ista, Fray Gerundio de Campazas, alias Zotes, ed. de R. P. Sebold, Madrid, 1992 (1ª ed. de 1758), pág. 437).
} 
las cofradías eran toleradas. Algunas, en concreto las sacramentales y de ánimas, eran consideradas como elementos imprescindibles del culto parroquial.

\section{Las cofradías. Distribución}

Según la encuesta realizada por la administración borbónica, a principios de la década de los setenta del siglo XVIII había en España 25.581 cofradías (19.024 en la corona de Castilla y 6.557 en la de Aragón) ${ }^{5}$. La distribución geográfica de estas instituciones era muy desigual y lo mismo podría decirse de las diferencias entre ciudades y zonas rurales. La encuesta realizada en el reinado de Carlos III a través de los intendentes nos muestra una realidad muy dispar; realizada por provincias, que tenían una extensión muy diferente, sus resultados nos permiten destacar la abundancia de cofradías en provincias poco extensas como Burgos, Toledo, Valladolid o León, pero en todo caso puede afirmarse que había cofradías en todas las regiones del país y en todos los pueblos y ciudades. En cada pueblo o aldea, por pequeño que fuera, había alguna cofradía y en las ciudades más importantes había una gran implantación de hermandades. Sevilla, Madrid y Toledo, con más de doscientas cofradías cada una, eran las ciudades con una mayor implantación cofradiera de España. La ciudad andaluza ${ }^{6}$ conservaba una primacía que había ostentado, sin duda, desde su época de máximo esplendor a fines del siglo xvı, cuando era la primera ciu-

${ }^{5}$ La información de la encuesta está contenida en el voluminoso Expediente General de Cofradías del Archivo Histórico Nacional, legs. 7090 y ss. Para una visión general del proceso que dio lugar a este expediente vid. A. Rumeu de Armas, op. cit., págs. 387-413; Farid Aвbар, «La confrérie condamnée ou une spontanéité festive confisquée: un autre aspect de l'Espagne a la fin de l'ancien régime», Mélanges de la Casa de Velázquez, vol. III (1977), págs. 361-384; Milagrosa Romero SAmper, «El Expediente General de Cofradías del Archivo Histórico Nacional. Regesto documental», Hispania Sacra, vol. XL (1988), págs. 205-234; Tomás Antonio Mantecón Movellán, Contrarreforma y religiosidad popular en Cantabria, Santander, 1990, págs. 173-186; Miguel Luis López Muñoz, «Control estatal de las asociaciones de laicos (1763-1814). Aspectos legales de la extinción de cofradías en España», en Emilio Laparra y Jesús Pradells (eds.), Iglesia, sociedad y estado en España, Francia e Italia. Siglos x уіI у хіх, Alicante, 1991, págs. 341-359; Milagrosa Romero SamPER. Las cofradías en el reformismo de Carlos III, Madrid, 1991; Inmaculada ArIas de SAAVEDRa y Miguel Luis López Muñoz, «El Expediente General de Cofradías (1769-1784). Propuestas para su estudio», en Iglesia y sociedad en el Antiguo Régimen. Actas III reunión científica de la Asociación Española de Historia Moderna, Las Palmas de Gran Canaria, 1995, págs. 31-40.

${ }^{6}$ Sobre cofradías sevillanas existe una bibliografía ingente, pero pueden mencionarse algunas obras de conjunto: S. Montoto de Sedas y E. Esquivias Franco, Cofradías sevillanas, Sevilla, 1976; Juan Carrero RodríGuEz, Anales de las cofradías sevillanas, Sevilla, 1984; VV. AA., Las cofradías de Sevilla. Historia, antropología, arte, Sevilla, 1985; VV. AA., Las cofradías de Sevilla en la Modernidad, Sevilla, 1988; Carlos José Romero Mensaque, El Rosario en Sevilla. Religiosidad popular y hermandades de gloria, Sevilla, 1990; del mismo autor, «Religiosidad popular y hermandades en la Sevilla del siglo XvII", Revista de Humanidades, 1 (1990), págs. 57-71; VV. AA., Las cofradías de Sevilla en el siglo de las crisis, Sevilla, 1991; Joaquín Rodríguez Mateos, «Las cofradías y las luces: decadencia y crisis de un fenómeno», en La Sevilla de las Luces, 
dad de España, y mantenía aún en el XVIII muchas cofradías fundadas en esta era de esplendor. El caso de Madrid era distinto ${ }^{7}$, respondía a fundaciones más recientes y el crecimiento de hermandades se había ido produciendo a la vez que la gran expansión urbana de la capital. Toledo ${ }^{8}$, por su parte, presenta un modelo similar al sevillano: la hipertrofia de cofradías se produce en una ciudad en amplia regresión y es muestra de la pervivencia de un rasgo tradicional de su pasado glorioso.

Pero más interesante que conocer el peso de las cofradías en cifras absolutas es intentar aproximarse a su significación relativa en el conjunto de la población. Relacionando el número de cofradías de las principales ciudades de España en 1771 y la población que tenían según el censo de Floridablanca de 1787, se observan algunas realidades interesantes 9 . Por ejemplo, Toledo era la ciudad donde las cofradías tenían una mayor implantación, pues había una cofradía por cada 87 habitantes. La antigua ciudad imperial tenía una fortísima presencia cofrade, sin duda un rasgo que evidenciaba su floreciente pasado con abundancia de fundaciones religiosas. Le seguía Valladolid, donde había una cofradía para apenas doscientos habitantes ${ }^{10}$. También aquí el peso de las asociaciones de laicos sería un recuerdo de tiempos mejores, concretamente de su brillante etapa cortesana, que era aún patente en el protagonismo de sus hermandades penitenciales, del cual han quedado numerosas muestras hasta la actualidad.

Valores muy parecidos presentaban Pamplona y Córdoba, con una cofradía por algo más de cada 280 habitantes, pero con grandes diferencias entre

\footnotetext{
Sevilla, 1991, págs. 132-147; J. Roda PeÑA, Hermandades sacramentales de Sevilla. Una aproximación a su estudio, Sevilla, 1996.

${ }^{7}$ Sobre cofradías madrileñas vid. los siguientes estudios de conjunto: Francisco Agullar Piñal, «Asociaciones piadosas madrileñas del siglo XVIII (Descripción bibliográfica de sus Constituciones)», Anales del Instituto de Estudios Madrileños, VII (1971), págs. 253-268; Jesús Pereira Pereira, «La religiosidad y la sociabilidad popular como aspectos del conflicto social en el Madrid de la segunda mitad del siglo XVIII», en EQUIPO MADRID de Estudios Históricos, Carlos III, Madrid y la Ilustración, Madrid, 1988, págs. 223-254; Virgilio Pinto Crespo, «Una reforma desde arriba: Iglesia y religiosidad», ibíd., págs. 155-188; Mª José del Rıo, «Represión y control de fiestas y diversiones en el Madrid de Carlos III», ibíd., págs. 299-329.

${ }^{8}$ Vid. sobre cofradías de Toledo: Mario Arellano García, «Datos para la historia de las parroquias de Toledo y las cofradías de las mismas», Toletum, 9 (1979), págs. 91-108; Hilario Rodríguez García, Cofradías Toledanas. Madrid, Reprografía de la Universidad Complutense, 1982, y Fernando Martínez GiL, Muerte y sociedad en la España de los Austrias, Madrid, 1993, págs. 403 y ss.

${ }^{9}$ Los datos datos relativos a número de cofradías, advocaciones y sedes de las principales ciudades españolas en Inmaculada Arias de Saavedra y Miguel Luis López-Guadalupe Muñoz, «Cofradías y ciudad en la España del siglo xvIII", Studia Historica, en prensa.

${ }^{10}$ De sus cofradías en el siglo xviII se han ocupado, entre otros, Jesús María Palomares Ibánez, La asistencia social en Valladolid. El Hospicio de Pobres y la Real Casa de Misericordia (1724-1847), Valladolid, 1975, págs. 102-117; Teófanes EGIDo, «La religiosidad colectiva de los vallisoletanos», en Luis Miguel Enciso Recio y otros, Valladolid en el siglo xVIII, Valladolid, 1984, págs. 157-260 y Elena MAZA ZorRiLLA, Valladolid: sus pobres y la respuesta institucional (1750-1900), Valladolid, 1985, págs. 57-65.
} 
ambas. El peso de las cofradías en una ciudad de tamaño relativamente pequeño, como la capital navarra ${ }^{11}$, se debía a la fortísima influencia en ella de la organización gremial aún en fecha relativamente tardía, como ocurre en otras ciudades de las zonas septentrional y oriental del país. La mitad de las cofradías pamplonesas eran de carácter gremial y muchas de ellas reducían su actividad a la celebración anual de las fiestas de sus santos patronos. El caso de Córdoba $^{12}$ era bien distinto. Como en Sevilla y Granada, que le siguen en importancia relativa, el auge de la actividad cofrade en estas ciudades y, en general, en el ámbito andaluz, respondía más bien al modelo de cofradía barroca que encarnó no sólo un tipo de religiosidad concreta, sino que también fue cauce y expresión de la sociabilidad popular con un marcado carácter festivo y lúdico. Eran aquí las cofradías una realidad mucho más visible y presente en la vida de la ciudad y probablemente estaban más en la mira reformista del gobierno ilustrado. La ciudad hispalense es aún hoy la que más se identifica en el inconsciente colectivo con la realidad cofrade. En cuanto a Granada, como se ha demostrado en estudios recientes, presentaba en el reinado de Carlos III una presencia cofrade también muy fuerte, que se había incrementado con nuevas fundaciones en los años inmediatamente anteriores.

Un peso relativo parecido tenían las cofradías en las ciudades norteñas de Bilbao y Santiago, donde había una cofradía por poco más de 400 habitantes. A pesar de un número relativamente alto de cofradías, en Valencia, Madrid y Barcelona la realidad cofrade parece bastante menor, dada su elevada población. Todas ellas sobrepasaban los 500 habitantes por cofradía. No son mas que conjeturas pendientes de comprobación, lo cuantitativo y lo cualitativo no son a veces coincidentes.

\section{Tipología, advocaciones y sedes}

La realidad cofrade era en la segunda mitad del siglo XVIII de una gran complejidad. Al lado de cofradías y hermandades propiamente dichas, con un

\footnotetext{
${ }^{11}$ Inmaculada Arias de SAavedra y Miguel Luis López Muñoz, «Cofradías y gremios en Navarra en la época de Carlos III», Hispania Sacra, 50 (1998), págs. 667-695.

12 Sobre sus cofradías vid., entre otros, los estudios de Juan Aranda Doncel, «Religiosidad popular en una ciudad andaluza del Antiguo Régimen. El movimiento cofradiero durante la segunda mitad del siglo xvIII en Córdoba», Boletín de la Real Academia de Córdoba, 113 (1987), págs. 55-78; Cofradías y asistencia social en los barrios de San Juan y Todos los Santos (Trinidad), Córdoba, 1990 y «Cofradías penitenciales y Semana Santa en la Córdoba del siglo xvII: el auge de la etapa barroca», en Actas del III Congreso Nacional de Cofradías de Semana Santa, Córdoba, 1997, vol. I, págs. 65-118; M. Castillejo Gorraiz, La religiosidad popular cordobesa, Sevilla, 1984 y Manuel Moreno Valero «Religiosidad popular en Córdoba en el siglo XviII. Cofradías del Santo Rosario», en Carlos Álvarez Santaló, Ma . Jesús Buxó y Salvador Rodríguez Becerra (coords), La religiosidad popular, Barcelona, 1989, vol. III, págs. 485-506.
} 
número de hermanos generalmente amplio, cuadros directivos bien estructurados y actividades regladas a lo largo de todo el año, existían las llamadas mayordomías, en las que la estructura organizativa de la cofradía era prácticamente inexistente. Se limitaban estas mayordomías a la celebración de las fiestas patronales, en las que participaban todos los vecinos, fiestas que solían ser costeadas por los mayordomos, elegidos por turno para tal fin. La mayordomía era la realidad cofrade más simple.

En cuanto a las cofradías propiamente dichas, aunque todas tenían como principal objetivo contribuir al culto divino y a la asistencia a sus miembros, según su distinta orientación, encontramos cofradías de diversos tipos: cofradías devocionales (las más frecuentes, que tenían como único objetivo el culto a la Virgen, los santos, el Santísimo Sacramento o las ánimas benditas del purgatorio), cofradías penitenciales (que se centraban en la conmemoración de la pasión y muerte de Jesucristo), cofradías gremiales (que junto a la faceta cultural tenían un componente profesional y reivindicativo muy claro) y cofradías asistenciales (donde la labor benéfica, existente en todas las cofradías en mayor o menor grado, adquiría una especial dimensión y salía del propio ámbito de sus hermanos; asistencia a pobres, hospitales, enseñanza eran sus principales objetivos). Por último hay que tener en cuenta un tipo de hermandades mucho más minoritarias, las congregaciones, que respondían a las necesidades espirituales de individuos más exigentes, con un nivel de formación a menudo mayor y con un sentido más elevado del compromiso cristiano. Algunas de estas asociaciones gozaron de una acusada personalidad, como las Escuelas de Cristo ${ }^{13}$ y las congregaciones de seglares creadas por la Compañía de Jesús. Alentaban la fe individual con prácticas tales, como meditación, pláticas, ejercicios espirituales, confesión y comunión frecuentes, etc.

Las advocaciones religiosas a las que se consagraban las cofradías eran muy variadas. Sin duda las más frecuentes eran las dedicadas a la Virgen. Las cofradías marianas estaban muy extendidas por toda la geografía española y, sin temor a equivocarnos, se puede aventurar que aproximadamente una tercera parte de las cofradías del reino respondían a esta advocación. Más de una tercera parte de las cofradías del reino de Navarra estaban dedicadas a la Virgen, y en el reino de Murcia alcanzaban el 31 por ciento. Por otra parte, en las ciudades de Murcia y Madrid las cofradías marianas rebasaban el 40 por ciento del total, y valores parecidos alcanzaban en Córdoba y Valladolid.

\footnotetext{
${ }^{13}$ Sobre la naturaleza de estas asociaciones vid. Francisco Moreno Valero, «La Escuela de Cristo. Su vida, organización y espiritualidad barroca», en C. Álvarez Santaló, Ma . J. Buxó y S. Rodríguez Becerra (coords.), op. cit., vol. III, págs. 507-528.
} 
Una de las devociones más frecuentes era la Virgen del Rosario, extendida por los dominicos, que había conseguido una gran implantación popular. En algunas ciudades solía haber varias hermandades rosarianas, en las distintas parroquias $^{14}$. Otras advocaciones marianas frecuentes eran Ntra. Sra. del Carmen, Ntra. Sra. de los Dolores, de la Esperanza, etc. En el siglo XvIII cobró cada vez más importancia una devoción mariana nueva, la Divina Pastora, que fue promovida por los capuchinos. No olvidemos tampoco que en muchos pueblos del país, sobre todo en Andalucía, solía haber una Virgen patrona de la localidad.

Seguían en importancia las cofradías dedicadas a los santos, que presentaban en conjunto valores próximos al 30 por ciento del total. En los reinos de Navarra y Murcia sobrepasaban claramente esta cifra. Las cofradías de santos ofrecían gran variedad de advocaciones, a menudo ligadas a las tareas del campo y a determinados oficios artesanales. Entre las primeras destacaban las de labradores y ganaderos, cuyas advocaciones más frecuentes eran San Isidro, San Antón, San Pascual Bailón, etc. Mayor importancia tuvieron las cofradías gremiales y profesionales, fenómeno netamente urbano, muy destacable en las principales ciudades del reino, especialmente en las del norte de país ${ }^{15}$.

En la ciudad de Pamplona casi el 60 por ciento de sus hermandades estaban dedicadas a diferentes santos. En Barcelona alcanzaban valores próximos al 50 por ciento y en Bilbao sobrepasaban el 40 por ciento. Por oficios destacaban las cofradías y gremios de zapateros, con los santos Crispín y Crispiniano como patronos, de sastres, con advocaciones muy variadas, de albañiles y carpinteros, dedicadas a San José, cuya devoción fue muy impulsada por la jerarquía eclesiástica en el siglo xvIII, dentro del esfuerzo por potenciar una religiosidad más humanizada y familiar; de tejedores, cordeleros, etc. En todos los pueblos y aldeas solía haber al menos una cofradía dedicada al santo patrón. Los santos más populares eran San José, San Francisco, San Antonio, San Sebastián (protector de la peste), San Miguel y San Juan.

Menor importancia numérica solían tener las cofradías dedicadas a alguna advocación de Cristo. Además de la consagradas a la devoción del Corazón de Jesús, devoción difundida por los jesuitas, o a diversos aspectos de la infancia de Cristo, promovidas estas últimas durante el siglo XVIII, destacaban sobre todo las destinadas a los cultos y procesiones de Semana Santa. Las cofradías peni-

${ }^{14}$ Es lo que ocurría, por ejemplo, en la ciudad de Sevilla. Vid. Carlos José Romero Mensaque, Estudio histórico de las hermandades de gloria de Nuestra Señora del Rosario de la ciudad de Sevilla y descripción artística de su patrimonio, Sevilla, 1990.

${ }^{15}$ Vid. al respecto los trabajos de J. de Contreras (Marqués de Lozoya), Historia de las corporaciones de menestrales en Segovia, Segovia, 1921; A. Rumeu de Armas, op. cit.; Pedro Molas Ribalta, Los gremios barceloneses del siglo XVIII. La estructura corporativa ante el comienzo de la revolución industrial, Madrid, 1970 y Siro Villas Tinoco, Los gremios malagueños (1700-1746), Málaga, 1982, 2 vols. 
tenciales con advocaciones de la Vera Cruz y del Nazareno eran las dominantes. Las de la Vera Cruz, promovidas por la orden franciscana, gozaban de numerosas indulgencias y privilegios pontificios y un fuerte respaldo popular. En casi todos los pueblos y aldeas solía haber alguna cofradía con esta advocación.

Aunque en menor número, las cofradías sacramentales y de ánimas abundaban en las parroquias. El culto al Santísimo Sacramento y a las ánimas benditas del purgatorio solía darse casi siempre en hermandades separadas, aunque a veces se hacía en el seno de una misma hermandad. Las hermandades sacramentales y de ánimas constituían un importante apoyo para el culto parroquial, por lo que, en general, eran bien vistas por las autoridades eclesiásticas. Llama la atención, sin embargo, el caso de Bilbao, donde no existía ninguna cofradía específicamente sacramental y los de Barcelona y Pamplona, donde sólo existía una cofradía de este tipo para toda la ciudad.

Por último, existían cofradías que se pueden calificar como mixtas. Entre ellas se encuentran bastantes que son al mismo tiempo sacramentales y de ánimas, y otras dedicadas a la Virgen y a un santo, a Cristo y a la Virgen (en el caso de algunas penitenciales), etc. Valladolid tenía un importante número de cofradías de este tipo, mientras que en Pamplona eran inexistentes, o casi en Barcelona y Córdoba. La presencia de este modelo de cofradías solía responder a procesos de fusión entre hermandades preexistentes, como medio de garantizar su supervivencia en tiempos de recesión. Mucho más escasas eran otras advocaciones como la Santísima Trinidad, Caridad, etc. Eran prácticamente irrelevantes. Solían responder más a asociaciones de corte espiritual y asistencial que a las típicas cofradías populares.

La inmensa mayoría de estas cofradías estaban ubicadas en iglesias parroquiales, sobre todo en el mundo rural, donde a menudo la parroquia era el único templo existente. En las ciudades las cofradías podían ubicarse también en otro tipo de sedes, como conventos, hospitales, basílicas, ermitas e incluso altares callejeros, no obstante, también en este caso la sede parroquial era la más frecuente. Las órdenes religiosas atrajeron a sus conventos numerosas cofradías; en las principales ciudades españolas, una tercera parte de sus cofradías estaban ubicadas en conventos. Las ciudades de Bilbao, Pamplona y Barcelona presentaban valores muy altos en este tipo de sedes. Este fenómeno no fue bien visto por las autoridades eclesiásticas, que veían así escapar del control de los ordinarios la actividad de las cofradías, a la vez que perderse las limosnas que podían completar las debilitadas economías parroquiales.

El resto de las sedes tenía mucha menor importancia. En Madrid y Córdoba contaban con cierta presencia las hermandades ubicadas en hospitales. 
Las cofradías ubicadas en ermitas y santuarios tenían importancia sobre todo en el mundo rural, aunque también utilizaban este tipo de sedes algunas cofradías urbanas de Córdoba, Granada, Murcia y Valladolid. En la ciudad de Córdoba un número importante de cofradías se hallaba ubicado en ermitas, lo que las hizo estar en la mira de los gobernantes ilustrados que veían con recelo los actos religiosos en estos templos, con frecuencia alejados del casco urbano y sin culto, que daban origen a romerías y otros actos, más de esparcimiento lúdico, que de religiosidad en sentido estricto y que eran ocasión de variados excesos $^{16}$. Algo parecido debió ocurrir en otras localidades meridionales como Sevilla.

\section{La implantación social de las cofradías}

Las cofradías durante la Edad Moderna son un fenómeno extensivo a todos los estamentos, que participan, en líneas generales, de una religiosidad común. Hasta bien entrado el siglo XVIII la religiosidad oficial y la religiosidad popular fueron en gran medida coincidentes en el mundo hispánico ${ }^{17}$. No obstante, los grupos privilegiados tendieron a crear corporaciones exclusivas, que les sirvieran para mostrar su posición privilegiada frente a las posibilidades de movilidad de grupos sociales en ascenso. La existencia de cofradías de nobles respondía claramente a esta intención y en el siglo XVIII poco tenían que ver con las hermandades militares surgidas en la Edad Media, aunque compartían idéntico espíritu estamental que aquellas.

Las cofradías nobiliarias fueron un fenómeno exclusivamente urbano, minoritario y con una clara tendencia al cerramiento. Podrían citarse muchos ejemplos de cofradías nobiliarias, como simple muestra pueden señalarse las cofradías de la Soledad de Barcelona y Sevilla, la de Santa María de Esgueva de Valladolid, que llegó incluso a tener jurisdicción privativa y la Santa Hermandad del Refugio y Piedad de Madrid ${ }^{18}$, que desempeñó una importante labor benéfica.

\footnotetext{
${ }^{16}$ Así, el intendente de Murcia, Antonio Carrillo de Mendoza, llegó a proponer en su informe el cierre al culto de estas ermitas (Inmaculada Arias de SaAvedra y Miguel Luis López Muñoz, «Religiosidad popular e Ilustración. Las cofradías en Murcia en 1771», Mélanges de la Casa de Velázquez, t. XXXI- 2 (1995), pág. 102).

${ }^{17}$ Sirvan como ejemplo de esta coincidencia los numerosos actos de desagravio a la Inmaculada Concepción celebrados en la ciudad de Granada en 1640 con motivo de la aparición de un libelo contrario a la misma. En ellos participaron las autoridades civiles y eclesiásticas, así como el pueblo más humilde, a través de fiestas religiosas promovidas por gremios y cofradías (Francisco Henríquez de Jorquera, Anales de Granada, Granada, 1987, vol. II, págs. 846-881).

${ }^{18}$ William J. Callahan, La Santa Hermandad del Refugio y Piedad de Madrid, 1618-1832, Madrid, 1980.
} 
De todos modos, el protagonismo de la nobleza en el mundo cofrade no se restringía exclusivamente a las cofradías nobiliarias. También era muy frecuente en el ámbito urbano que una hermandad de base popular reclutase en sus filas a determinados nobles, que desempeñaban un especial protagonismo, como mecenas y protectores de la institución. A ellos se recurría para costear obras de arte y solían ocupar un lugar destacado en las procesiones, portando la insignia de la hermandad. La conexión con la cofradía se solía transmitir en la familia de padres a hijos.

Por su parte, el otro estamento privilegiado, el eclesiástico, también formó sus propias hermandades grupales, especialmente los sacerdotes. En su caso, la cofradía no respondía tanto a un mecanismo de diferenciación social, sino a las necesidades asistenciales de sus miembros. Las cofradías de clérigos actuaban como mecanismo de solidaridad en las diversas necesidades de un clero no siempre bien remunerado, sobre todo en sus bases. Auxilio en la enfermedad, acompañamiento en el entierro, encargo de sufragios por las almas... son algunos de los fines de estas cofradías. La mayoría estaban bajo la advocación de San Pedro, pero menos frecuentemente aparecen bajo la advocación de otros santos clérigos como San Ildefonso, San Fulgencio o San Juan Nepomuceno.

Otros grupos sociales crearon también hermandades exclusivas. Así existen ejemplos de hermandades exclusivamente femeninas (como la de Santa Águeda de Barcelona), de otras que agrupan a miembros de determinadas corporaciones (miembros de cabildos municipales, catedráticos universitarios, magistrados de justicia, militares, etc.).

Pero, sin duda, el ámbito corporativo más importante, respecto a las cofradías, fue el mundo de los gremios. Uno de los rasgos más característico del mundo cofrade en el ámbito urbano es la presencia de cofradías gremiales. A veces cofradía y gremio se confunden, otras veces mantienen su autonomía y entre uno y otro extremo se constatan diversas situaciones intermedias ${ }^{19}$. Las atribuciones específicas de la cofradía gremial parecen claras: el culto al santo patrón y, en su caso, algunas medidas benéficas a favor de los agremiados.

Aunque este tipo de hermandades se extienden a todos los oficios, incluso a los más poderosos y con una organización gremial más fuerte, su significación es especialmente destacable en los oficios no agremiados e incluso en las profesiones liberales, donde la hermandad se convertía en un sucedáneo de la estructura gremial, proporcionando a sus miembros una plataforma relevante en la sociedad urbana. Así se manifiesta en las prestigiosas cofradías de abo-

${ }^{19}$ A. Rumeu de Armas, op. cit., págs. 73-92 y P. Molas Ribalta, op. cit., pág. 50 y ss. 
gados, médicos, notarios, escribanos, oficiales de justicia, etc... y, por el otro extremo, en las cofradías de carniceros, $\operatorname{cocheros}^{20}$, «ganapanes», etc...

Es destacable la presencia del mundo gremial a través de sus cofradías en las festividades religiosas, especialmente en la solemne procesión del Corpus Christi $^{21}$. La compleja escala jerárquica del Antiguo Régimen se hacía visible en este acto público, en el que, junto a autoridades y cabildos, los gremios desfilaban por prelación establecida, no exenta de disputa, en función de su importancia social y su antigüedad. En ocasiones, como ocurría en Madrid o en Barcelona, fueron los gremios los encargados de acompañar los «pasos» de Semana Santa.

Asimismo, en festividades civiles, proclamaciones de reyes, visitas reales, etc., los gremios se encargaban del ornato de la ciudad, cada uno en sus calles y barrios respectivos. En las ciudades donde los oficios eran muy poderosos era muy destacable la contribución económica realizada por los gremios como «gastos extraordinarios» con ocasión de este tipo de festejos así como de calamidades públicas. El ámbito propio de manifestación del gremio era la fiesta patronal. Solía coincidir con el relevo de las autoridades del oficio y prestaba ocasión para la rivalidad, en el terreno simbólico, entre los gremios. Esta rivalidad se hacía patente en gastos excesivos, conflictos de precedencia, etc.

En el ámbito de la «economía moral» que caracteriza al Antiguo Régimen, las cofradías gremiales ofrecían en sus distintos patronos modelos a seguir por los artesanos, que combinaban el virtuosismo y la laboriosidad en el oficio con cualidades morales y espirituales. De ahí que fuera frecuente entronizar la imagen de los patronos de los oficios, no sólo en las capillas de los templos-sede, sino también en los lugares de trabajo, en forma de hornacinas y altares callejeros, ante los que siempre solía arder alguna ofrenda de cera. De esta forma se contribuía también a la sacralización del espacio público.

Pero no todo era armonía. La simple presencia de hermandades de mancebos en distintos oficios, evidencia las tensiones laborales entre maestros y oficiales, que utilizaron la hermandad como cauce de autoafirmación. Ello a pesar de que las hermandades de oficiales estaban expresamente prohibidas por las leyes desde la época de Carlos $\mathrm{V}^{22}$.

\footnotetext{
${ }^{20}$ Antonio Domínguez Ortiz, «Aspectos sociales de las cofradías sevillanas. Un memorial de las cofradía de las Tres Caídas, de San Isidoro, en defensa de los cocheros», Archivo Hispalense, XXX, n 93-94 (1959), págs. 167-170.

${ }^{21}$ Vid. Vicente LLeó Cañal, Fiesta Grande. El Corpus Christi en la historia de Sevilla, Sevilla, 1980, p. 27.

22 Pragmática de Carlos V de 1552, Novísima Recopilación, libro XII, título XII, ley XIII (A. Rumeu de Armas, op. cit., pág. 203).
} 
Por último, no se completaría esta visión sobre la implantación social de las cofradías sin hacer referencia al amplio colectivo de los marginados, que tenían una importancia numérica muy relevante en la sociedad del Antiguo Régimen. El extenso y variado mundo de la marginación social no era ajeno tampoco a la realidad de las cofradías. Ya como protagonistas, ya como receptores de las actuaciones cofrades, encontramos a pobres, gitanos, esclavos, etc. La presencia de cofradías étnicas es especialmente significativa en la España meridional. Para estos marginados la pertenencia a una cofradía revestía una especial significación. Ser miembro de una cofradía era en un determinado momento un testimonio de afirmación simbólica frente a las clases dominantes. El caso es particularmente conocido en la cofradía de negros sevillana, estudiada por Isidoro Moreno ${ }^{23}$. Otro ejemplo es el de las cofradías de ciegos, repartidas prácticamente por las principales ciudades españolas, que se preocuparon por mejorar el nivel de vida económico y la dignidad social de estos discapacitados, obteniendo a veces diversos privilegios económicos. Pero sobre todo no olvidemos que al complejo mundo de la marginación destinaban sus esfuerzos las hermandades de caridad y de misericordia. Sus actuaciones eran muy amplias, básicamente se dirigían a paliar la pobreza en todas sus manifestaciones.

A veces se constata la existencia de cofradías para atender sectores específicos. Dos ejemplos, de inspiración jesuítica, pueden destacarse. Uno de ellos es la atención a la población reclusa, en sus necesidades tanto materiales como espirituales ${ }^{24}$, desarrollando una ingrata tarea en uno de los ambientes más sórdidos del Antiguo Régimen. El otro es la presencia en el mundo de la prostitución, aunque con un sesgo más moral que asistencial en sus actividades $^{25}$.

\section{Esquema organizativo}

Como ya se señaló al principio, desde finales de la Edad Media se sucedió en nuestro país la fundación de cofradías. Aunque muchas de ellas desa-

\footnotetext{
${ }^{23}$ Isidoro Moreno, La antigua hermandad de los negros de Sevilla. Etnicidad, poder y sociedad en 600 años de historia, Sevilla, 1997.

${ }^{24}$ Pedro Herrera Puga, Sociedad y delincuencia en el Siglo de Oro, Granada, 1971, págs. 187-218.

${ }^{25}$ Así en Granada la cofradía jesuítica del Espíritu Santo intentaba la regeneración de las prostitutas en el beaterio de Santa María Egipciaca (Miguel Luis López Muñoz, La labor benéfico-social de las cofradías en la Granada Moderna, Granada, 1994, págs. 125-130). En Madrid la congregación de Nuestra Señora de la Esperanza regentaba la Casa Real de Santa María Magdalena que acogía a solteras embarazadas (Gloria Franco Rubio, La Iglesia secular de Madrid en el siglo xviI. Estado socioeconómico, Madrid, Reprografía de la Universidad Complutense, 1986, págs. 215-216).
} 
parecían después de una vida más o menos larga y eran sustituidas por otras distintas, en otros casos se restablecían fundaciones antiguas.

En principio correspondía a la autoridad eclesiástica la autorización de estas corporaciones. Sin duda la mayoría de las cofradías contaron con la aprobación del obispo de la diócesis, cuando las hermandades tenían su sede en las parroquias, o del superior de las órdenes religiosas, en el caso de estar radicadas en conventos. En otros casos, que también debieron de ser numerosos, ni siquiera se solicitaba esta aprobación y se consideraba obtenida de forma tácita, una vez que el instituto llevaba funcionando un tiempo. En algunas ocasiones, poco frecuentes por cierto, la cofradía obtenía la aprobación papal, casi siempre en la forma de concesión de bulas e indulgencias. Este tipo de aprobación papal, al margen de la autoridad del ordinario, solía producirse sobre todo a principios del siglo XVI, antes de la celebración del concilio de Trento.

Más rara era la aprobación por parte de la autoridad civil, a través de un permiso otorgado por el Consejo de Castilla, máximo organismo de gobierno interno del país. Muy pocas cofradías contaron con este permiso, lo que justificaría las medidas tomadas contra ellas durante el reinado de Carlos III. La aprobación real evidenciaba más la condición de súbditos de los cofrades que el carácter religioso de la asociación.

Se conocen bastantes datos acerca de la estructura organizativa de las hermandades españolas en el siglo XVIII. La mayoría de las constituciones no fijaban requisitos especiales para ser admitido como hermano ni establecían un número fijo de individuos, de forma que estaban formadas por hombres y mujeres, y tenían un número de cofrades muy variado, sobre todo dependiendo de que la cofradía se ubicara en pequeñas aldeas o en ciudades importantes. De todos modos, la cofradía tipo solía situarse en torno a cien hermanos, hombres y mujeres, aunque el protagonismo masculino era mucho mayor y los varones copaban los cargos directivos de la hermandad. En otros casos, de ciudades importantes, o de devociones especialmente populares, se pueden encontrar ejemplos de cofradías con un número muy elevado de cofrades, llegándose a sobrepasar incluso a los 1.000 afiliados; es lo que ocurre en la hermandad de Santa Cruz de Caravaca y en numerosas Órdenes Terceras, por sólo citar unos ejemplos.

En algunos casos las cofradías establecían mumerus clausus para sus individuos. Casi siempre se trataba de números con una especial significación simbólica: 12 y 24 (por los apóstoles), 33 y 72 (por las edades de Jesús y María, según la tradición), 15 (por los misterios del Rosario) y 100, cifra en la que con mayor frecuencia se constituían las cofradías cerradas. 
Mas frecuentes eran los mecanismos de cerramiento de carácter estamental o grupal ${ }^{26}$. Ya nos hemos referido antes a las cofradías nobiliarias o de clérigos y a las muy abundantes, sobre todo en las ciudades, cofradías gremiales, que agrupaban a personas del mismo oficio o de la misma actividad económica, fuera o no agremiada. En otros casos, el efecto excluyente se conseguía por medio del establecimiento de condiciones para la admisión, elevadas cuotas, o la aprobación de los hermanos para las nuevas admisiones.

Por lo que se refiere a la estructura organizativa y al funcionamiento interno de las cofradías, si se exceptúan las mayordomías, que, como se señaló antes, eran una simples fiestas, las cofradías solían tener una serie de cargos para el gobierno del instituto. Cuando este gobierno era unipersonal, las cofradías solían estar presididas por el hermano mayor o mayordomo, oficios que aparecen con mayor frecuencia. El oficio de hermano mayor tiene un carácter más representativo, mientras que el de mayordomo tenía una dimensión más económica, con la obligación de costear la fiesta, aunque a veces se daba a ambos cargos un significado sinónimo. En ocasiones el título que recibe quien dirige la cofradía es el de prior, director, prioste, rector, etc., pero en todo caso el contenido de sus atribuciones era bastante parecido y se ceñía a la toma de decisiones y a la máxima representación del instituto. En otros casos el gobierno de las cofradías era colegiado, entre un número variable de mayordomos, casi siempre en número par: dos y cuatro suelen ser los números más frecuentes, pero en ocasiones aparecen seis mayordomos o un número sin especificar. Junto a hermano mayor y mayordomo, podían aparecer otros cargos como secretario, tesorero o administrador, diputados, limosneros, comisarios de cuentas, vocales, etc...; todos ellos eran hermanos «oficiales». El número de cargos directivos, reducido a principios de la Edad Moderna, tendió a multiplicarse a partir del siglo XVII.

La designación de los cargos era muy variada, la más extendida era sin duda la elección anual, pero también era muy frecuente la utilización del sorteo y el turno entre los hermanos para el desempeño de los cargos, no faltando incluso el ofrecimiento de voluntarios en algunas hermandades, o la cooptación. Se trataba, en general, de procedimientos democráticos, aunque no exentos de rivalidades, dentro de una Iglesia eminentemente jerárquica. En cuanto a la duración de estos cargos, lo habitual es que fueran de carácter anual, renovándose en el cabildo general, aunque la práctica de la reelección fue bastante frecuente en las cofradías españolas. A veces podía darse la renovación parcial de cargos.

${ }^{26}$ Vid. Claude Chauchadis «Les modalités de la fermeture dans les confréries religieuses espagnoles (xviexvıI siecles)», en el colectivo Les societés fermées dans le monde iberique (xvie-xvIIIe Siècles), Paris, 1986, págs. 83-105. 
La mayoría de las hermandades celebraban varias juntas generales al año, a las que debían asistir todos los hermanos. Muchas hermandades tenían también juntas particulares, es decir juntas de los oficiales para distintos aspectos del gobierno y administración del instituto. En ocasiones este tipo de juntas sustituyó a las generales, pero con frecuencia simultaneó su existencia con el cabildo general de la hermandad. Por lo que se refiere a la frecuencia en la celebración de las juntas, en una abrumadora mayoría las cofradías tenían solamente una junta al año, aunque no faltan algunos casos en que celebraban dos o tres. En asociaciones de características específicas, como Congregaciones, Órdenes Terceras o Escuelas de Cristo, el número de juntas solía ser superior, alcanzando en ocasiones la periodicidad mensual o incluso mayor, pero entre las cofradías propiamente dichas rara era la que se reunía más de dos veces al año ${ }^{27}$ y en estos casos solía celebrar una junta general y otra particular.

\section{Los recursos económicos}

Según la encuesta realizada por los intendentes hacia 1771 las más de 25.000 cofradías españolas entonces existentes realizaban unos gastos anuales superiores a 11,5 millones de reales, lo que suponía unos gastos medios por cofradía en torno a 450 reales al año.

Aunque la capacidad económica de las diversas cofradías era muy desigual, dicha encuesta nos permite aproximarnos a la distinta realidad económica en las diferentes regiones españolas. Las cofradías más ricas se situaban en el sur y en el Levante español, en las provincias de Sevilla, Valencia, Murcia y La Mancha, cuya cifra media de gastos sobrepasaba los 700 reales anuales ${ }^{28}$. Estas cifras medias se rebasaban con frecuencia si se tiene en cuenta, por ejemplo, que algunas cofradías murcianas recaudaban sólo de las rentas fijas procedentes de sus bienes (sin tener en cuenta limosnas ni cuotas) cantidades anuales que sobrepasaban los 5.000 reales.

Seguían con gastos superiores a la media las provincias de Toledo, Córdoba, Extremadura, Segovia y Valladolid, con gastos entre 450 y 700 reales. Por debajo

${ }^{27}$ Es lo que ocurría en la Hermandad de las Angustias de Granada celebraba tres juntas generales al año, en los meses de enero, mayo y septiembre, y al menos dos juntas de oficiales, con motivo de las elecciones y de tomar las cuentas al mayordomo saliente (Miguel Luis López Muñoz, «Las Ordenanzas de la Hermandad de Nuestra Señora de las Angustias de Granada en el siglo xvı», Chronica Nova, 17 (1989), págs. 388-389).

${ }^{28}$ La distribución del gasto medio en las distintas provincias españolas en Inmaculada Arias de SAAVEDRA y Miguel Luis López MuÑoz, «Debate político y control estatal de las cofradías españolas en el siglo XVIII», Bulletin Hispanique, t. 99 (1997), no 2, págs. 429 y 430. 
de la media de gastos se situaban las provincias orientales de Cataluña, Aragón, las castellanas de León, Palencia, Ávila y Toro, así como Guipúzcoa, con gastos entre 200 y 450 reales al año. Las cofradías más pobres, o al menos las que menos gastos anuales declararon, fueron las de la Cornisa Cantábrica, zona oriental de la Meseta y buena parte del País Vasco, es decir, las provincias de Galicia, Asturias, Burgos, Soria, Álava, Vizcaya y Navarra, con gastos anuales inferiores a 200 reales al año.

Las fuentes de ingresos de las cofradías eran muy variadas. Muchas cofradías poseían una hacienda propia. Se trataba de rentas procedentes de la explotación de tierras, arrendamientos de fincas, de intereses de censos y de otros derechos. Estas propiedades y fuentes de ingresos procedían, por lo general, de donaciones de cofrades y devotos, muchas de ellas hechas en disposiciones testamentarias. Las rentas procedentes de la tierra solían ser las más frecuentes. En muchas ciudades las cofradías poseían fincas urbanas ${ }^{29}$ y más esporádicamente aparecen locales comerciales e industriales como tiendas, talleres, hornos, molinos, etc. En las áreas urbanas era fácil la conjugación entre las rentas de la tierra y de inmuebles.

En menor medida las cofradías obtenían ingresos procedentes de censos y de otros derechos, como los derivados del uso del agua del riego, que eran muy característicos de la región murciana ${ }^{30}$. Muy frecuentes eran los censos en forma de memorias de misas, que condicionaban la percepción de una renta a la celebración de misas por el alma del donante.

Pero junto a estos ingresos, la estabilidad económica mínima de una cofradía se garantizaba gracias a las aportaciones de los hermanos: las cuotas. Las modalidades de cuotas más comunes eran la de ingreso (o de «entrada») y la ordinaria (también llamada «luminaria»). La cuota de entrada se satisfacía por una sola vez y solía ser relativamente elevada, por ejemplo en la hermandad del Rosario de Lorca suponía la cantidad de 75 reales. La cuota ordinaria, satisfecha por años, por meses o incluso por semanas, era sin duda la más frecuente, casi siempre era una cantidad relativamente baja en torno a 5 reales anuales por hermano, aunque no faltan ejemplos de cantidades aún más bajas, como un real al año. Aunque más baja que la cuota de entrada, era esta cuota ordinaria, por su continuidad, el más firme aporte a la economía de las cofradías en muchos casos.

\footnotetext{
${ }^{29}$ Según datos procedentes del Catastro de Ensenada, más del 80 por ciento de las cofradías de la ciudad de Granada obtenían ingresos procedentes de los alquileres de casas de su propiedad (Miguel Luis LópEZ Muñoz, «Aproximación a los ingresos de las cofradías de la ciudad de Granada a través del Catastro de Ensenada», en Actas del II Congreso de Historia de Andalucía, Andalucía Moderna II, Córdoba, 1995, págs. 380-382).

${ }^{30} \mathrm{Vid}$. al respecto I. Arias de Sanvedra y M. L. López Muñoz, «Las cofradías de Murcia en 1771», pág. 87.
} 
Además de estas cuotas ordinarias, con frecuencia las cofradías cobraban cuotas extraordinarias, para satisfacer gastos de difícil previsión. Las más extendidas eran las cobradas con ocasión del fallecimiento de algún hermano, para sufragar los gastos de entierro y más frecuentemente las misas en sufragio por su alma. La práctica más extendida era el pago de dos reales por cada hermano, y en otras ocasiones el satisfacer el estipendio correspondiente a una misa rezada.

Otra fórmula de aportación de los cofrades era la derrama, prorrata o escote, es decir, el reparto equitativo de los gastos de la hermandad (o de determinadas funciones) entre los hermanos. Cuando las cantidades de estas derramas eran muy altas nos encontramos ante auténticos mecanismos de cerramiento que intentan limitar el acceso a la cofradía de nuevos hermanos. A mayor esfuerzo económico, mayor prestigio social de cara a la comunidad.

También los hermanos podían participar económicamente a través de las limosnas solicitadas por las cofradías, pero las demandas eran ante todo una fórmula para solicitar fondos a toda la comunidad, al conjunto de los vecinos que participaban así en las necesidades económicas de las cofradías. Estas demandas públicas solían solicitarse en la ciudad, en la calle, de casa en casa, recogidas principalmente en dinero, y también en el campo, limosnas recogidas en las tierras de labor, generalmente en la época de la cosecha y recaudadas en especie. También se realizaban demandas en los templos, a la puerta de los mismos o en cepillos en su interior, con ocasión de las festividades religiosas de las cofradías. Las demandas públicas constituían una fuente de ingresos fundamental en el sostenimiento de las cofradías. Su producto era muy elevado en las cofradías de mayor devoción y era especialmente relevante lo destinado a los sufragios de difuntos, por ello no es de extrañar que las cofradías de ánimas fueran grandes recaudadoras de este tipo de limosnas ${ }^{31}$.

Otras fuentes de ingresos muy variadas como rifas, bailes, corridas de toros ${ }^{32}$, etc. tenían una menor significación. No obstante, eran con frecuencia objeto de atención por las autoridades eclesiásticas que las consideraban nocivas y contrarias al fin religioso de estos institutos y por ello eran blanco de aceradas críticas. pág. 90).

${ }^{31}$ Algunas cofradías de ánimas de Murcia recaudaban miles de reales al año para estos sufragios (Ibid.,

${ }^{32}$ Celebraba corridas de toros, por ejemplo, la hermandad de San Isidro de Madrid. En contadas ocasiones algunas cofradías obtenían permiso para celebrar corridas anualmente, es lo que le ocurrió a la Hermandad de las Angustias de Granada, por real cédula de 21 de noviembre de 1747, para costear con los fondos de estos festejos su hospital (Miguel Luis y Juan Jesús López-Guadalupe Muñoz, Nuestra Señora de las Angustias y su hermandad en la época moderna, Granada, 1996, pág. 125). 
En cuanto al destino de los fondos, las posibilidades de gasto de las cofradías eran muy variadas. Los gastos fundamentales, pues corresponden a los propios fines de la asociación, eran los gastos de culto: celebración de misas, tanto en las festividades de la cofradía como en sufragio por las almas de los hermanos difuntos, pago a predicadores en ocasión de festividades extraordinarias, gastos de cera, ornato y mantenimiento de las Iglesias (no olvidemos que algunas cofradías tenían sus propio templos-sede o mantenían el culto en ermitas o santuarios). Las cofradías más modestas celebraban la festividad de su patrón al menos con una misa anual. Frecuentemente los actos de culto eran más numerosos y se distribuían a lo largo de todo el año, en forma de misas, memorias de difuntos y sobre todo ampliando la festividad principal con novenas, vísperas, etc. El capítulo de la cera para estas festividades religiosas era importantísimo y en muchas cofradías lo gastado en este concepto podía equipararse a los gastos de culto en sentido estricto. La cuota extraordinaria tenía como fin hacer frente a la compra de cera, al menos originariamente.

Pero no todo el dinero de las cofradías se gastaba en actos relacionados con el culto. La crítica ilustrada con frecuencia clamaba contra otros gastos de las cofradías ${ }^{33}$ que eran calificados de ostentación, boato y profanidad. Los gastos más frecuentes eran los destinados a comidas y otras celebraciones entre los cofrades, a pólvora e iluminación artificial para las fiestas que acompañaban los actos estrictamente religiosos y en menor medida a los gastos en música. Aunque por lo general estos gastos superfluos no eran muy elevados, o al menos así lo declaraban las cofradías cuando eran interrogadas por las autoridades, no faltan casos en que el volumen de estos gastos sobrepasaba a las cantidades pagadas estrictamente en los actos de culto.

\section{Actividades de las cofradías}

La actividad principal, reglamentada en los estatutos de las cofradías, es la promoción de los actos de culto. Las posibilidades en este ámbito eran muy variadas, oscilando entre aquellas hermandades que celebraban una sola función anual a su titular, hasta las que promovían funciones regulares todos los meses, todas las semanas e incluso todos los días.

${ }^{33}$ Son frecuentes los testimonios en este sentido. Así, Pablo de Olavide se mostraba clamaba contra las abundantísimas cofradías sevillanas que «causaban la ruina de muchas familias por el errado concepto que tienen de preferir estos gastos, que en la mayor parte se ejecutan por emulación y ostentación, a las obligaciones esenciales que los padres de familia tienen de proveer...» (Citado por Inmaculada Arias de SAavedra y Miguel Luis López Muñoz, «Debate político y control estatal...», pág. 425). 
La función principal solía ser la destinada al patrón o titular. Generalmente consistía en una misa con sermón y procesión, acompañada con frecuencia con un función de vísperas la tarde anterior. En las hermandades sacramentales esa función se celebraba el día del Corpus, el de su octava o el domingo intermedio (domingo infraoctavo).

Muchas cofradías celebraban una misa mensual, a veces cantada y sobre todo rezada. Las hermandades sacramentales la solían acompañar de una procesión eucarística por el interior del templo, con manifestación del Stmo. Sacramento; son las llamadas Minervas, por el nombre de la basílica romana donde se inició esta práctica ritual. Estas cofradías también realizaban la adoración eucarística de las XL horas ${ }^{34}$.

Las cofradía marianas solían celebrar de modo especial las cinco festividades de María: Anunciación, Asunción, Natividad, Concepción y Purificación, que solía acompañarse de la llamada procesión de las «candelas», de especial protagonismo cofrade. El culto a las imágenes titulares se prolongaba en algunos casos durante un número determinado de días consecutivos. Son los novenarios, dedicados sobre todo a la Virgen, quinarios (a los Cristos) y septenarios y triduos. Las hermandades rosarianas rezaban los misterios del rosario generalmente en el interior del templo, pero a veces realizaban rosarios callejeros, vespertinos, nocturnos o de la aurora.

Algunos de los cultos de las cofradías se solían celebrar en días fijos de la semana. Las hermandades marianas solían celebrar sus cultos en sábado: misa sabatina, con el rezo de la salve; las de ánimas los lunes y las penitenciales los viernes. La misa diaria era propia de las hermandades con sede propia (iglesia-sede, ermita u hospital), con lo que se aseguraba el culto permanente.

Junto al culto a los titulares, las cofradías no descuidaban la labor asistencial respecto a sus afiliados. La preocupación por los difuntos era esencial, tanto en el aspecto material como en el espiritual. La fórmula más frecuente era el aniversario de difuntos, bien en el mes de noviembre o coincidiendo con la festividad de la hermandad. En algunas hermandades los cultos por los difuntos eran mensuales y en las de ánimas diarios. Las hermandades de ánimas destinaban a sufragios la totalidad de sus fondos ${ }^{35}$.

\footnotetext{
${ }^{34}$ Para lo referente al culto eucarístico vid. $\mathrm{M}^{\mathrm{a}}$ del Pilar Bertos Herrera, El tema de la Eucaristía en el arte de Granada y su provincia, Granada, 1986, 2 vols.

35 Una información más detallada de la actividad de estas hermandades en Miguel Luis López Muñoz, «Consideraciones sobre la muerte en las cofradías de ánimas de la ciudad de Granada», en Carlos Álvarez SANtaló y Ma del Carmen Cremades Griñán, en Actas III Reunión Científica de la Asociación Española de Historia Moderna. Mentalidad e Ideologías, Murcia, 1993, págs. 293-304.
} 
Además de los sufragios, las cofradías prestaban atención al hermano en el momento de morir. Por los datos conocidos, no cabe duda de que en el siglo XVIII esta atención constituía la actividad benéfica más importante y extendida de las cofradías. En ocasiones el entierro era costeado por la propia cofradía, sobre todo si el hermano era pobre, pero en todo caso la hermandad asistía, con su paño, la cera y las insignias. Las órdenes terceras solían aportar un hábito para mortaja del difunto e incluso asistían al entierro los religiosos del conventosede. Se celebraban gran cantidad de sufragios: generalmente una misa de réquiem y un número variable de misas rezadas, tampoco faltaban vigilias y responsos. Las hermandades con hospital propio se encargaban del entierro de los enfermos del mismo y no faltaban las destinadas al entierro de ajusticia$\operatorname{dos}^{36}$.

Gran cantidad de hermandades celebraban actos externos de culto, fuera del ámbito de las Iglesias, es decir, procesiones de diverso tipo. La modalidad más extendida era la procesión mariana o patronal, seguida de la procesión del Corpus (generalmente en hermandades sacramentales) y las procesiones de Semana Santa, a cargo de cofradías penitenciales. Menor incidencia tenían las procesiones del viático (propias también de las hermandades sacramentales) y los rosarios callejeros.

Sin ser el acto externo de culto más generalizado en las cofradías del Antiguo Régimen, quizá sea la Semana Santa la actividad cofradiera de mayor proyección social en la vida urbana, a la vez que la de mayor continuidad a lo largo de los siglos, hasta el punto de que actualmente la palabra cofradía casi sugiere esta realidad procesional. Es significativo que esta faceta de la actividad cofrade, que sin duda fue la más vigilada e incluso reprimida durante el Antiguo Régimen, haya sido la de mayor pervivencia hasta el momento actual.

Protagonistas de la Semana Santa eran las hermandades de penitencia. Nacidas muchas de ellas durante los siglos xV y xVI, casi siempre en sedes conventuales, pronto se ubicaron también en parroquias y contaron con una espectacular acogida popular ${ }^{37}$. Las más poderosas llegaron a contar con sus propios templos-sede, como ocurría en Sevilla y Valladolid, donde realizaban sus cultos con más independencia y con un menor control por parte del clero. El modelo de cofradía penitencial fue haciéndose cada vez más complejo, llegándose a la «cofradía barroca», con numerosas imágenes que protagonizaban extensos y suntuosos desfiles procesionales. Las cofradías penitenciales, que siempre se con-

\footnotetext{
${ }^{36}$ José Luis Gómez Undáñez, La Hermandad de la Sangre de Cristo de Zaragoza. Caridad y ritual religioso en la ejecución de la pena de muerte, Zaragoza, 1981.

${ }^{37}$ José Sánchez Herrero, «Las cofradías de Semana Santa durante la modernidad. Siglos Xv a XviII», en Actas del I Congreso Nacional de Semana Santa, Zamora, 1987, págs. 27-68.
} 
taron entre las más ricas, fueron creando una Semana Santa paralela a la oficial, centrada esta última en la celebración del triduo sacro. Esta paraliturgia, alentada inicialmente por la propia jerarquía eclesiástica y más tarde vista con recelo, contó siempre con un apoyo popular mayor que las prácticas litúrgicas oficiales. Y ello por su marcado carácter lúdico, por la unión indisoluble, en la mentalidad popular, entre práctica religiosa y fiesta que se da en la Semana Santa. Una práctica religiosa que se desarrolla en el escenario urbano, recorriendo sus calles y templos principales. La estación de penitencia en diversos templos, no sólo en la catedral, era entonces habitual, contribuyendo a sacralizar aún más un espacio ya impregnado de connotaciones religiosas.

La Semana Santa era también el escenario privilegiado para la representación del orden social vigente ${ }^{38}$ y el lugar donde se dirimían las rivalidades entre las propias hermandades de penitencia. Multitud de pleitos, relativos al orden de paso, así lo atestiguan, pero también la rivalidad simbólica en imágenes, enseres, etc., que nos ha dejado amplias muestras de mecenazgo artístico y un género propio, la imaginería policromada naturalista y procesional. Como se ha señalado, los problemas de competencia y rivalidad enmascaraban con frecuencia enfrentamientos de clase más profundos. No es raro que existieran hermandades grupales entre las penitenciales, bien nobiliarias, bien étnicas, y sobre todo de oficios. La participación gremial fue siempre muy destacada en la Semana Santa, llegando en algunos casos (Barcelona o Madrid) a estar regulada por las autoridades municipales.

También participaban las cofradías en otros fastos religiosos que tenían por escenario la ciudad. Una festividad tan importante como la del Corpus gozaba de la presencia de las cofradías gremiales y penitenciales, acompañadas de una amplia representación del clero secular y de las distintas órdenes religiosas locales. Esta procesión que gozaba de una gran solemnidad, también contaba con elementos paganos como tarascas, gigantes, etc., algunos de los cuales han pervivido hasta la actualidad ${ }^{39}$. El desfile por las principales calles engalanadas, donde se habían construido altares, puesto toldos, adornado el suelo con flores y plantas olorosas, solía estar acompañado con la celebración de autos sacramentales, comedias a lo divino, etc. Algunas de estas prácticas: autos sacramentales, gigantes, etc., serían prohibidas en el reinado de Carlos $\mathrm{III}^{40}$.

${ }^{38}$ Vid. al respecto Federico Fernández Basurte, «La representación de la sociedad local a través de la procesión de Semana Santa», en Actas del Simposium sobre la religiosidad popular en España, San Lorenzo del Escorial, 1997, págs. 627-643.

${ }^{39}$ V. Lleó Cañal, op. cit., págs. 24-42 y Miguel Garrido Atienza, Antiguallas granadinas. Las fiestas del Corpus (Ed. facsímil. Estudio preliminar de José Antonio González Alcantud), Granada, 1990, págs. 73 y ss.

${ }^{40}$ La real cédula de 10 de julio de 1780 prohibía las danzas y gigantones en las iglesias que tenían lugar con motivo de la festividad del Corpus (Novísima Recopilación, libro I, título I, ley XII). 
La presencia cofradiera es más destacable en procesiones generales y rogativas que tenían lugar con ocasión de especiales circunstancias, como epidemias, sequías, terremotos, inundaciones, guerras, etc. Presidían estas procesiones algunas imágenes de "probada eficacia» ${ }^{41}$, titulares a menudo de cofradías concretas. Con frecuencia tales manifestaciones, concebidas como actos colectivos de toda la ciudad, eran convocadas por las autoridades municipales. Sirva de ejemplo la procesión general celebrada en Málaga con ocasión del terremoto de Lisboa.

Tampoco faltó la asistencia cofrade en las manifestaciones festivas de las órdenes religiosas, sobre todo con ocasión de la canonización de algunos de sus miembros ${ }^{42}$. En estas apoteosis frailunas las cofradías, ocupando su lugar, se manifestaban como uno de los más brillantes logros del proselitismo de cada convento.

La presencia corporativa de las cofradías en todos estos actos públicos que acabamos de reseñar contribuyó a reforzar aún más su identidad dentro del mundo urbano. Como una corporación más de la ciudad participaba en los actos públicos, en el lugar que le correspondía y en torno a su insignia identificativa. Era una clara muestra de afirmación social.

Las cofradías desempeñaron una importante actividad benéfica. Lo más frecuente es que esta actividad benéfica se redujera a sus afiliados, en forma de sufragios por el alma de los cofrades fallecidos y de auxilios en el momento de morir, como se ha señalado antes. Menos frecuente era el caso de las cofradías hospitalarias, que rebasan con mucho la solidaridad entre cofrades y se abrían a la asistencia externa, atendiendo las más diversas necesidades. Escasas en número, por la exigencia de recursos que precisa cualquier centro «hospitalario», inviable sin dotaciones económicas sólidas, su realidad asistencial, salvo en casos excepcionales (Hermandad del Refugio de Madrid, Hermandad de la Caridad de Sevilla, Hermandad de la Caridad y Refugio de Granada ${ }^{43}$ ), fue poco relevante.

La mayoría tenía que contentarse con costear el mantenimiento de unas cuantas camas, repartir algunas limosnas y recaudar fondos para dotes. Merece destacarse su valor testimonial, que representa un grado de exigencia y com-

\footnotetext{
${ }^{41}$ Sobre el valor taumatúrgico de las imágenes procesionales vid. Juan Antonio SÁnchez López, Muerte y cofradías de pasión en la Málaga del siglo XVIII (La imagen procesional del barroco y su proyección en las mentalidades), Málaga, 1990, págs. 47-58.

${ }^{42}$ Sirvan de ejemplo las fiestas celebradas en Granada en 1622 con motivo de las canonizaciones de San Ignacio, San Francisco Javier y Santa Teresa de Jesús (F. Henríouez de Jorquera, op. cit., pág. 647.

${ }^{43}$ Vid. al respecto Miguel Luis López Muñoz, La labor benéfico-social de las cofradías en la Granada moderna, Granada, 1994, págs. 76 y ss y Juan Ignacio Carmona García, Los hospitales en la Sevilla Moderna, Sevilla, 1980, págs. 42-49.
} 
promiso entre los laicos superior a lo habitual. Como era lógico en aquella época se atendía lo mismo a la salud del cuerpo que a la del alma, aunque más a esta segunda. Pero no conviene equivocarse. En el fondo eran un mecanismo más para paliar desigualdades muy acusadas, sin socavar los cimientos estructurales de la sociedad del Antiguo Régimen. En ese sentido, pueden inscribirse, como hace Callahan, en un pacto tácito entre necesitados y benefactores ${ }^{44}$.

Es frecuente rastrear en estas hermandades benéficas la presencia de los sectores más acomodados de la sociedad urbana. Ejercían la caridad cristiana y, sobre todo, lo hacían públicamente, ofreciendo ejemplos de virtud que, sin duda, no pasaban desapercibidos. Muy significativos resultan los entierros de ajusticiados, actos sociales de pública compasión, que solían correr a cargo de hermandades de caridad y misericordia. En Madrid existieron al menos dos cofradías para estos fines, que realizaban sus tareas con gran solemnidad ${ }^{45}$. Algunas alcanzaron un notable grado de especialización asistencial, sobre todo en el terreno de la infancia, preocupándose del sustento y educación de los niños más desfavorecidos.

Las cofradías no reducían su actividad meramente al culto y a la beneficencia. Limitar su visión a estos aspectos es pecar de reduccionismo. Las cofradías constituían uno de los pocos cauces, casi el único en área rurales, para el asociacionismo y el fomento de relaciones interpersonales.

Gracias a ellas, muchas gentes sencillas se sentían amparadas, mediante la pertenencia a unas asociaciones de larga tradición y continuidad en el tiempo, que acentuaban la solidaridad entre sus miembros en momentos difíciles, especialmente enfermedad y muerte, y brindaban frecuentes ocasiones de sociabilidad, expansión y diversión a unas vidas no muy sobradas de ocio y esparcimiento. La fiesta religiosa tuvo siempre un componente lúdico insoslayable, que la Iglesia llegó a potenciar incluso como medio de exaltación religiosa. No sólo los actos externos, como procesiones y romerías, sino también los actos de culto, proporcionaban a los cofrades ocasiones para reunirse. No hay que olvidar, sin embargo, que algunas prácticas lúdicas estaban preñadas de significación religiosa al menos en su origen (es el caso de las comidas entre los cofrades), en un horizonte mental en que la frontera entre lo sagrado y lo profano era difícilmente discernible. pág. 67.

${ }^{44}$ William J. Callahan, «Caridad, sociedad y economía en el siglo xvIII», Moneda y crédito, 140 (1978),

45 Se trataba de las hermandades de la Caridad y de la Paz, de la Iglesia de Santa Cruz, que asistían al entierro de los que morían por la justicia. Cuidaban de que a los reos se les diera la Sagrada Comunión, de que les asistieran religiosos en el patíbulo y de darles sepultura, además de pagarles sus deudas, si no eran muy cuantiosas (José Antonio Álvarez y BaENa, Compendio histórico de las grandezas de la coronada villa de Madrid..., Madrid, 1786, págs. 73 y 74). 
También proporcionaban las cofradías, al menos a algunos de sus miembros, la posibilidad de protagonismo social, mediante el desempeño de cargos directivos, mayordomías, etc., que a buen seguro constituían uno de los escasos medios de afirmación social, a pesar de suponer una carga económica a veces notable e ineludible para los vecinos por cuestión de honor. Aún más, en el caso de las cofradías grupales (gremiales, estamentales...), constituían un mecanismo más de defensa de intereses socio-económicos, que podía traducirse, llegado el caso, en obtención de ciertos privilegios.

Por último, las cofradías podían ser un medio de manifestación y afirmación de la identidad colectiva local o comarcal. Las fiestas patronales son el máximo exponente de esta faceta, que se manifiesta también en aspectos externos como utilización de elementos del folklore, de las tradiciones populares, etc...

\section{La iglesia y las cofradías}

Ante las dimensiones del fenómeno cofrade no es de extrañar que la Iglesia prestara atención al fenómeno, intentando regularlo, ponerlo bajo el control de su jerarquía y reformar ciertas prácticas que podían ser consideradas cuando menos poco convenientes a unas asociaciones con fines religiosos.

En el terreno eclesiástico, ya el concilio de Trento adoptó una postura definida respecto a estas instituciones para que fuera seguida en todo el ámbito católico. Consistía básicamente en poner las cofradías, como el resto de las fundaciones laicas con carácter religioso, bajo el control de los obispos, control que se materializaría por medio de visitas periódicas a estas instituciones de los oficiales del obispado ${ }^{46}$.

En España las disposiciones del concilio de Trento relativas a las cofradías fueron desarrolladas por el episcopado encargado de aplicar sus principios. Los concilios provinciales y sínodos diocesanos, celebrados periódicamente, prestaron una gran atención al fenómeno cofrade. Los textos de estos sínodos y concilios son una fuente de expresión privilegiada de la actitud de la jerarquía eclesiástica $^{47}$, durante prácticamente toda la Edad Moderna, pues, como es bien sabido, el espíritu de Trento permaneció vigente en los siglos siguientes.

\footnotetext{
${ }^{46}$ Vid. Ignacio López de Ayala, El sacrosanto y ecuménico Concilio de Trento, traducido al idioma castellano por..., Madrid, 1819, págs. 314-315.

${ }^{47}$ Un análisis de estas disposiciones en Inmaculada Arias de SaAvedra y Miguel Luis López-Guadalupe Muñoz, "Auge y control de la religiosidad popular andaluza en la época de la Contrarreforma», en Actas del Congreso Internacional: Felipe II (1598-1998). Europa dividida: la monarquía católica de Felipe II, Madrid, 1998, tomo III, págs. 37-61.
} 
Las visitas a las cofradías existentes y el permiso del ordinario para crear nuevas fundaciones son aspectos sobre los que vuelven insistentemente las constituciones sinodales. El arzobispo de Granada, Pedro Guerrero, reclamaba la intervención de los funcionarios episcopales e insistía en la necesidad de revisar los estatutos de las hermandades de nueva creación e incluso de las ya existentes ${ }^{48}$. La visita a las cofradías debía ser anual. El arzobispo de Sevilla, don Fernando Niño de Guevara, daba instrucciones muy precisas de cómo debía realizarse ésta, llevando una contabilidad exhaustiva de todas las cofradías, rentas e incluso actos de culto ${ }^{49}$.

Las cofradías con sede en conventos fueron objeto de atención en las constituciones sinodales porque gozaban de una mayor independencia. Se trataba de ponerlas bajo el control de los obispos, pero esta aspiración no siempre fue conseguida.

Por lo general la autoridad eclesiástica se preocupó bastante por la selección de los individuos que se ocupaban del gobierno de las cofradías, tratando de evitar la excesiva permanencia en los cargos, prescribiendo la elección anual de los mismos, sobre todo en los casos en que las cofradías tenían bienes propios, para evitar el posible abuso en su administración.

Una parte sustancial de la visita, prescrita en Trento, se destinaba al control económico de la institución. Como ya se ha señalado, muchas cofradías tenían bienes, la Iglesia tenía un especial interés en salvaguardar este patrimonio y ponerlo a cubierto de administradores desaprensivos, evitando ventas y enajenaciones. En todo caso, tuvieran o no bienes, las cofradías estaban obligadas a presentar cuentas periódicas al obispado.

También prestó la jerarquía eclesiástica una especial atención a las demandas públicas realizadas por las cofradías, intentando restringirlas, ya que la sociedad estaba sometida a una presión limosnera muy fuerte. Aunque las demandas públicas no desaparecieron, quedaron restringidas a aquéllas que obtuvieran el permiso del ordinario. Las únicas demandas que siempre contaron con permiso eclesiástico eran las destinadas al Santísimo Sacramento, ánimas del purgatorio y fábricas de las Iglesias, lo que demuestra por parte de la autoridad eclesiástica la voluntad de reforzar el culto parroquial. También la concesión de estas licencias se jerarquizó.

\footnotetext{
${ }^{48}$ Constituciones sinodales del arzobispado de Granada, hechas por el Ilustrísimo Reverendísimo Señor Don Pedro Guerrero, Arzobispo de la Santa Iglesia de Granada, en el Santo Synodo que S.S.R. celebró a quatorce días del mes de octubre de 1572, Granada, 1573, pág. 110.

${ }^{49}$ Constituciones del arçobispado de Sevilla, hechas i ordenadas por el ilustrísimo y reverendísimo señor Don Fernando Niño de Guevara, Cardenal i Arçobispo de la Santa Iglesia de Sevilla... Sevilla, 1609.
} 
Especial atención tuvieron los obispos por el destino de los fondos de las cofradías, preocupándose por evitar que se empleasen en gastos superfluos e inútiles. Las comidas celebradas por los cofrades eran el despilfarro más frecuente, amenazando algunas constituciones sinodales con no aceptar las cuentas de las cofradías si se realizaban tales gastos. No obstante, la frecuencia con la que se recuerda la prohibición de estos gastos superfluos pone de manifiesto que nunca se lograron erradicar.

Si las autoridades eclesiásticas prestaron atención a los aspectos organizativos y jurisdiccionales de las cofradías, mayor aún fue su interés por supervisar sus actividades de culto. El concilio de Trento reforzó considerablemente la estructura parroquial de la Iglesia y las cofradías fueron consideradas un posible aliado para reforzar los actos de culto. Las cofradías debían contribuir a mantener la debida dignidad y ornato de los templos, realizar los sufragios contenidos en sus estatutos, una vez que la Iglesia había establecido el valor de estos sufragios, y debían contribuir al reforzamiento del culto eucarístico que se experimentó después del concilio.

Pero el aspecto al que la jerarquía eclesiástica prestó una mayor atención fue las manifestaciones externas de culto, que sin duda son las expresiones más acabadas de la religiosidad popular representada por las cofradías. Si en los aspectos organizativos de las cofradías primaron sobre todo las orientaciones jurisdiccionales, respecto a la religión «en la calle» la Iglesia postridentina optó por vigilar las cuestiones de doctrina y de moral, con una doble intención: por un lado vigilar la ortodoxia de los mensajes que se transmitían (para que fueran acordes con los principios que se acababan de definir) y por otro diseñar una estrategia ideológica o pastoral de exaltar la fe cristiana en todo momento y lugar ${ }^{50}$.

La regulación y control de las estaciones de penitencia fue objeto de profusa atención en las constituciones sinodales, para depurar estas manifestaciones de culto de cualquier adherencia impropia. Se insistía en la recomendación de no celebrar sermones ni procesiones nocturnas, por los excesos que de tales concurrencias multitudinarias se pudieran derivar. En Sevilla, sólo la procesión de la Vera Cruz escaparía a esta prohibición. En Málaga, Fr. Alonso de Santo Tomás ordenaría en 1671 que todas las iglesias permanecieran cerradas la noche del jueves al viernes santo ${ }^{51}$. En todas las diócesis se hacían obligatorias las licencias para procesionar, se señalaban horarios e itinerarios y se intentaba redu-

\footnotetext{
${ }^{50}$ Vid. V. Pinto Crespo, op. cit., págs. 182-185 y J. Pereira Pereira, op. cit., págs. 244-245.

${ }^{51}$ Constituciones synodales del obispado de Málaga, hechas y ordenadas por... Fr. Alonso de Santo Tomás, Sevilla, 1674, pág. 434 .
} 
cir las estaciones de penitencia a miércoles, jueves y viernes santos. Se intentaba así mismo imponer la autoridad de la parroquia en las procesiones.

Pero el verdadero caballo de batalla en cuanto a la Semana Santa fueron las procesiones de disciplinantes ${ }^{52}$, verdadera bestia negra de la documentación sinodal. Aunque la Iglesia en general admitía que la disciplina corporal, a imitación de la padecida por Cristo, era una práctica loable, la experiencia demostraba que podía dar paso a aspectos muy negativos (desorden, poca devoción, vanidad, profanidad, incitación a la concupiscencia, etc.). Por eso no es de extrañar que en numerosas constituciones sinodales (Guadix, Sevilla, Málaga, etc.), se deslicen juicios de valor negativos sobre estas procesiones de disciplinantes ${ }^{53}$ y se vayan imponiendo una serie de cautelas para regular esta práctica. Desde la actitud silenciosa y devota que han de tener los disciplinantes, a la imposición del anonimato y de un atuendo modesto y adecuado, que impida su identificación, la restricción de la presencia de mujeres, o la prohibición de alquilar disciplinantes y de quebrantar el ayuno a causa de la disciplina; las recomendaciones sobre este aspecto son muy prolijas.

A pesar del esfuerzo regulador de las prácticas de los disciplinantes, en este punto, como en tantos otros relativos a las cofradías, los abusos descritos no se erradicaron en la práctica. Esto explicaría que este tipo de procesiones estuviera siempre en la mira de la autoridad eclesiástica y civil y acabaran por ser prohibidas definitivamente en $1777^{54}$.

Aunque las procesiones de Semana Santa fueron objeto de una intensa regulación, no son las únicas que atrajeron la atención sinodal. El Corpus Christi fue también objeto de especial atención. Las sinodales no sólo se preocuparon de reforzar su celebración, recordando la obligatoriedad de esta procesión, sino que intentaron realzarla, instando a las cofradías a su participación en ellas. Lo mismo ocurría con la procesión del viático, para administrar la eucaristía a enfermos e impedidos.

También se preocupó la jerarquía eclesiástica de regular todo lo relativo a otras procesiones como las generales de San Marcos, las de la Ascensión de Jesús, o las del Rosario, de tanto arraigo popular. En todas ellas, tras el concilio de Trento, se hizo una llamada a la responsabilidad sobre la disciplina eclesiás-

${ }^{52}$ Vid. José Sánchez Herrero, «La disciplina pública como fenómeno penitencial barroco», en C. Álvarez Santaló, Ma J. Buxó y S. Rodríguez Becerra (coords.), op. cit., vol. II, págs. 528-539.

${ }^{53}$ Synodo de la diócesis de Guadix y Baza, celebrado por... don Martín de Ayala, año de 1554, Alcalá de Henares, 1556 (Ed. facsímil con estudio preliminar de Carlos Asenjo Sedano, Granada, 1994), f. 66 v.; Constituciones del arzobispado de Sevilla..., págs 97 y 98; Constituciones synodales del obispado de Málaga..., pág. 498.

${ }^{54}$ La Real Cédula de 20 de febrero de 1777 prohibía los disciplantes y empalados en las procesiones, así como los bailes en las iglesias y en sus atrios (Novísima Recopilación, libro I, título I, ley XI). 
tica, para velar por la devoción, modestia y honestidad requerida en todas estas manifestaciones religiosas.

Por último, se detecta en las autoridades eclesiásticas el interés por desterrar una serie de prácticas profanas que frecuentemente iban unidas a las manifestaciones de la religiosidad popular y en concreto de las cofradías. A la necesidad de corrección de estos abusos dedican bastante extensión las constituciones sinodales y sabemos que en la mayor parte de las ocasiones con poco éxito en la práctica, debido a que el componente lúdico de estas manifestaciones las hacía muy difíciles de erradicar.

Sin duda las más extendidas eran las prácticas comensales, ya aludidas. Los cofrades comían y bebían con ocasión de las principales fiestas, a veces incluso en el interior de las iglesias (por ejemplo, había cenas en templos y sacristías los jueves santos en Málaga). No hay que desdeñar los valores religiosos y solidarios de tales prácticas, al menos en su origen. De ahí que con frecuencia se llamaran caridades ${ }^{55}$. Aunque las quejas sobre estas prácticas son frecuentes, las autoridades se estrellaron con la resistencia popular ${ }^{56}$. Y es que estas fiestas eran una de las pocas ocasiones de solaz y esparcimiento que se ofrecían a las clases populares. El control de estas prácticas se hacía más necesario con ocasión de romerías en templos alejados de las poblaciones, donde se ofrecían situaciones más difíciles de controlar: gran afluencia de público, jornadas que se prolongaban hasta altas horas ${ }^{57}$, promiscuidad de sexos, etc. La pervivencia en nuestro país de numerosas romerías a lo largo de los siglos nos muestra lo vano de las pretensiones de la jerarquía eclesiástica en su intento de eliminar o al menos encauzar estas prácticas.

Como puede observarse, a través de todas las disposiciones que acerca de las cofradías emanaron de la autoridad eclesiástica se fue perfilando un modelo de cofradía/hermandad acorde con las directrices tridentinas. Un modelo que se inspira en conceptos como ortodoxia, sujeción al ordinario, moralidad de costumbres y aprovechamiento espiritual de los fieles. El mismo Carlos III daría ejemplo con su participación en la Congregación de Alumbrado y vela del Santísimo Sacramento, fundada en la capilla de la corte, que se convertiría

\footnotetext{
${ }^{55}$ Unas interesantes páginas sobre el comensalismo de las cofradías en T. A. Mantecón Movellán, op. cit., págs. 159-172.

${ }^{56}$ A. Peñafiel Ramón, Mentalidad y religiosidad popular murciana en la primera mitad del siglo xviII, Murcia, 1988.

${ }^{57}$ Es lo que ocurría, por ejemplo, en la romería celebrada en la ermita de San Miguel de Granada (Luis Núnez Contreras, La Hermandad de San Miguel de Granada, Granada, 1963, pág. 72). Los abusos de la romería fueron tales que en 1770 la cofradía fue suprimida fulminantemente (M. L. LóPEz MuÑoz, «Control estatal de las asociaciones de laicos», pág. 346).
} 
en un modelo imitado por las elites urbanas en algunas ciudades importantes del reino ${ }^{58}$.

Es evidente, sin embargo, que la práctica de las cofradías y, en general, las variadas expresiones de religiosidad popular, no se ajustaron al modelo ortodoxo que la autoridad eclesiástica intentó imponer. Abusos y desviaciones hubo siempre y prueba de ello es que la política reformista de la Iglesia y del Estado en el Setecientos volvió a incidir en los mismos aspectos denunciados en la documentación sinodal. Pero ya en esa época, de intensificación del control sobre las manifestaciones religiosas populares, se detecta un progresivo alejamiento de la religiosidad oficial respecto a la religiosidad popular. Un testimonio muy vivo de esta nueva actitud lo tenemos en los informes que los metropolitanos realizaron en $1769^{59}$ a instancias del Consejo de Castilla, dentro de la actuación general respecto a las cofradías que se realizó en el reinado de Carlos III, con el fin de reducir su número.

La actuación gubernamental respecto a las cofradías se inició por la denuncia ante la autoridad civil del obispo de Ciudad Rodrigo, Cayetano Cuadrillero, acerca de los abusos cometidos por determinadas hermandades de su diócesis. A raíz de esta denuncia Campomanes inició la actuación del Consejo, recomendando hacer una consulta previa a las autoridades eclesiásticas. Aunque no todos los arzobispos que respondieron a la consulta, que fueron efectivamente sólo cinco, tuvieron la misma postura a la hora de informar sobre la realidad cofrade, al menos en algunos de ellos se detecta una actitud muy crítica respecto a las cofradías, que pone de manifiesto el progresivo alejamiento que, al menos en una parte de la autoridad eclesiástica, se había ido produciendo respecto de la religiosidad popular.

Especialmente interesante es la postura de los arzobispos de Tarragona, Juan Lario y Lancis, quien presenta la posición más crítica respecto a las cofradías y sintoniza más con la postura ilustrada del gobierno, y del arzobispo de Burgos, José Javier Rodríguez de Arellano, en cuyo informe se trasluce un cierto escepticismo, dictado por su propia experiencia pastoral fallida en el intento de erradicar males muy arraigados de las cofradías.

Ambos consideran que las cofradías se habían desviado de su espíritu y fines primitivos, que existían en número excesivo y que eran objeto de exce-

${ }^{58}$ Sumario de las indulgencias perpetuas y parciales concedidas... a la Real Congregación de Alumbrado y Vela al Santísimo Sacramento..., Granada, 1848. En Granada, por ejemplo, se creó una hermandad similar a la que pertenecía lo más granado de la elite local, entre otros los miembros de la Sociedad Económica de la ciudad.

${ }^{59}$ Un análisis de estos informes en Inmaculada Arias de SaAvedra y Miguel Luis López Muñoz, «Informes de los metropolitanos en el expediente general de cofradías (1769)», Publicaciones, 25-26-27 (Melilla, 1997), págs. 17-54. 
sos innegables, especialmente de gastos excesivos. El arzobispo de Burgos cuenta su propia experiencia al intentar moderar estos despilfarros en gastos de vino y comilonas y dice que las cofradías respondieron «que no habría cofradías si no había vino», siendo los gastos más excesivos en las cofradías de gentes más pobres. El arzobispo de Tarragona insistía también en este mismo aspecto, señalando la cantidad de personas que se arruinaban en el desempeño de cargos de mayordomos, por no ser menos que sus antecesores. También se aludió a gastos excesivos en vestidos, cera, pólvora, etc., e incluso a otras prácticas desviadas que tenían un carácter más local. Así, el arzobispo de Tarragona describió con detalle las rifas y bailes fomentados por las cofradías, que consideraba inmorales.

Pensaban ambos prelados que del establecimiento de cofradías en los conventos se derivaban consecuencias muy negativas para las parroquias (por el desvío de misas, entierros, donativos, etc. que esto supone). Muy radical, Juan Lario, sugirió que en lo sucesivo se prohibieran nuevas fundaciones en los conventos y que se trasladaran las cofradías existentes en éstos a los templos parroquiales. No se olvide que el proceso contra las cofradías fue paralelo a la reforma de los regulares ${ }^{60}$. El arzobispo tarraconense describió también los excesos ocasionados en las procesiones nocturnas de Semana Santa, proponiendo que fueran prohibidas, así como las romerías en ermitas que solían celebrarse los domingos de Resurrección.

Ambos prelados no desdeñaron solicitar el apoyo de la autoridad civil para corregir los abusos y excesos de las cofradías. Y en cuanto a las medidas de actuación futuras, ambos prelados consideraron que debían subsistir únicamente las cofradías del Stmo. Sacramento, ánimas y alguna de la Virgen y las de los patronos de cada pueblo, el resto debían desaparecer y en lo sucesivo debían limitarse las nuevas fundaciones.

La propuesta más drástica fue la del arzobispo de Tarragona, concretada en cinco puntos de actuación: prohibición de nuevas fundaciones, incluso en los templos parroquiales, reducción de las cofradías existentes a un número conveniente, concentración de las rentas e indulgencias de las cofradías que fueran eliminadas en las que subsistieran, traslado de las cofradías con sede en los conventos a los templos parroquiales y prohibición de cualquier tipo de gasto superfluo, así como de las procesiones nocturnas y romerías. Todo un programa de reforma en el controvertido campo de la religiosidad popular. No es extraño

\footnotetext{
${ }^{60}$ Sobre este tema vid. Antonio Luis Cortés Peña, La política religiosa de Carlos III y las órdenes mendicantes, Granada, 1989.
} 
que este informe fuera recibido con el mayor agrado por el Consejo y tuviera más influencia en actuaciones posteriores.

Sin embargo no debemos pensar que la actitud de los obispos de Tarragona y Burgos era general en la jerarquía eclesiástica durante la época ilustrada. Sus puntos de vista contrastan bastante con los expresados por otros metropolitanos que también contestaron al requerimiento del Consejo (los arzobispos de Zaragoza, Granada y el gobernador de la archidiócesis de Sevilla, que contestó en lugar del arzobispo de esta ciudad).

El punto de vista de estos otros metropolitanos no era tan crítico como los antes reseñados y, aunque se veían obligados a admitir excesos que había que corregir, no eran partidarios de suprimir cofradías ni de cambios drásticos. La fuerte realidad cofrade en sus arzobispados, particularmente en Andalucía, explicaría esta actitud contemporizadora. Está claro que los prelados no querían malquistarse con sus feligreses y es posible también que personalmente sintonizaran con estas formas de expresión de la religiosidad popular, más que con actitudes más serias y rigurosas y menos dadas al boato y a la expresión externa que venían perfilándose en la nueva corriente de espiritualidad que ha venido a ser llamada «religiosidad ilustrada». Ésta, partidaria más de la piedad interior, de la actitud personal e individual desgajada de las prácticas externas, era minoritaria y no abarcaba a toda la jerarquía eclesiástica.

\section{La acción del estado}

No es extraño que, creada una opinión contraria a ciertas manifestaciones de la religiosidad popular en los círculos ilustrados, el gobierno emprendiera una política de reforma dirigida a las cofradías. Pero no conviene exagerar los móviles religiosos de los reformadores, aunque sin duda los hubiera. Las razones económicas y de orden público fueron decisivas a la hora de actuar sobre estos excesos, especialmente los protagonizados por las cofradías.

A los gobernantes les preocupaba especialmente los elementos profanos que se mezclaban con los actos de culto, las aportaciones económicas, a veces muy sustanciosas, exigidas a los hermanos, la reducción del número de jornadas laborales con la profusión de fiestas, e incluso la creación de situaciones potencialmente peligrosas para el orden público, como podía ocurrir en determinadas romerías, situaciones particularmente temidas tras las oleadas de motines de 1766.

Las primeras actuaciones borbónicas respecto a las cofradías tuvieron lugar en el reinado de Fernando VI y están referidas concretamente a la villa de Madrid. 
En 1752 se corrigieron algunos abusos de las procesiones sacramentales y en 1757 se regularon las penitenciales ${ }^{61}$. Pero fue durante el reinado de Carlos III, cuando el Consejo de Castilla, presidido por el conde de Aranda, se mostró especialmente sensible a los abusos de las cofradías. Diversos expedientes de hermandades madrileñas llegados al Consejo fueron calificados muy duramente y propiciaron el inicio de la actuación del fiscal Campomanes para proceder al control de estas asociaciones de laicos. Las denuncias del obispo de Ciudad Rodrigo, antes citadas, lo convencerían de la necesidad de actuación.

Al mismo tiempo comenzaban a restringirse algunas prácticas de las hermandades, en especial algunos medios de obtener ingresos. En 1766 se prohibían las demandas a las cofradías madrileñas. Entre estas primeras actuaciones, destaca en 1767 la prohibición de las congregaciones jesuíticas de laicos (muy similares a las cofradías), consecuencia lógica del decreto de expulsión de la Compañía.

El 22 de febrero de 1769 Campomanes emitió un dictamen decididamente partidario de la reforma de las cofradías y se envió una circular a todos los arzobispos pidiendo información sobre las cofradías de su jurisdicción. Era sólo una primera toma de contacto. En septiembre de ese año se ordenaba a los intendentes de la Corona de Castilla y a los corregidores de la Corona de Aragón la elaboración de un censo de las hermandades de sus distritos, debiendo constar sus advocaciones y sedes, sus fiestas, gastos anuales y si tenían o no aprobación real ${ }^{62}$.

Mientras se confeccionaban los informes, el gobierno seguía restringiendo las prácticas de la piedad popular, suprimiendo elementos paganos adheridos a ellas, como los gigantones y tarascas en las procesiones del Corpus madrileño, en 1772, medida que se haría extensiva a todo el reino en 1780.

La información de la encuesta de intendentes y corregidores, incompleta y desigual, forma el Expediente General de Cofradias. Recibida la mayor parte de la información, el presidente del Consejo, Aranda, expuso sus tesis, muy extremas, ante los consejeros el 9 de agosto de $1773^{63}$. En síntesis proponía la extinción de las cofradías de ánimas y nacionales, recordando también la prohibición

${ }^{61} \mathrm{M}^{\mathrm{a}}$ José del Río, op. cit., págs. 306 y 309.

${ }^{62}$ Un análisis de los informes de intendentes y corregidores en Inmaculada Arias de SAavedra y Miguel Luis LóPEZ MuÑoz, «La política ilustrada ante la religiosidad popular. Intendentes y cofradías en el reinado de Carlos III», en Pablo Fernández Albaladejo, José Martínez Millán y Virgilio Pinto Crespo (coords.), Política, religión e Inquisición en la España moderna. Homenaje a Joaquín Pérez Villanueva, Madrid, 1996, págs. 85-105.

${ }^{63}$ Un exhaustivo análisis de la postura del conde de Aranda en Inmaculada Arias de SAavedra y Miguel Luis LópEz Muñoz, «El conde de Aranda ante la religiosidad popular. Releyendo el informe sobre cofradías de 1773», en Actas del Congreso Internacional «El conde de Aranda y su época», Zaragoza, 1998, en prensa. 
de las gremiales (legislada desde el reinado del emperador Carlos $\mathrm{V}$ y repetida reiteradamente sin éxito) y la prohibición de los rosarios callejeros, mientras permitía la subsistencia de las hermandades sacramentales y de socorro.

Con los datos de la encuesta, el contador Manuel Navarro elaboró un «extracto general» que presentó al Consejo el 30 de octubre de 1775. En toda España había 25.581 cofradías que realizaban gastos anuales por un valor global superior a 11,5 millones de reales. Un mes más tarde, el procurador general del reino, Vicente Paino, presentó al rey un nuevo informe en el que consideraba necesaria la aprobación real para la continuidad de las cofradías y proponía suprimir las hermandades gremiales y las que tenían sede en santuarios, despoblados, capillas, calles y portales, así como las establecidas en conventos de regulares, dejando subsistir sólo las que tenían su sede en las parroquias, para reforzar así la autoridad del clero diocesano. Sin embargo, no se mostraba partidario de una reducción radical.

Después el Expediente sufrió un importante retraso. Las causas del mismo fueron varias, por un lado la salida de Aranda del Consejo y su marcha como embajador a París hizo perder al proyecto uno de sus principales valedores, pero además influyó el que las autoridades desearan ligar la suerte de las cofradías a la incipiente organización de la beneficencia pública. En caso de suprimirse alguna cofradía, sus fondos ya tendrían un destino claro: las juntas de caridad. El reglamento de la junta de Madrid, creada en 1778 y modelo para las demás del reino, se hacía eco de los perjuicios religiosos causados por las cofradías: su «abolición aumentará la concurrencia de los fieles a su Parroquia y librará a los vasallos de un peso intolerable, haciéndose pobres muchas familias con las comilonas y gastos superfluos que hacen en estas Cofradías, especialmente quando llegan a ser oficiales en ellas, en que suele sobresalir la vanidad más que la devoción ${ }^{64}$.

Por fin, el 28 de abril de 1783, Campomanes presentaba al Consejo sus conclusiones definitivas, que insistían en los argumentos de carácter económico para actuar sobre las cofradías: «El número excesivo de fiestas que celebran anualmente, las cantidades que invierten en gastos de luxo y profusión, los desórdenes que se cometen en tales concurrencias, los empeños que contrahen los prebostres, priores, maiordomos o hermanos maiores para salir con lucimiento en sus oficios, el trabajo y jornales que pierden respectivamente los cofrades asistiendo a las fiestas y juntas, y las derramas y contribuciones con que se gravan y atrasan, faltando tal vez a las primarias obligaciones de su estado, son otros tantos poderosos motibos que convencen la necesidad de dar curso al Expe-

${ }^{64}$ Novísima Recopilación, lib. I, tit. II, ley VI, nota 5. 
diente y tomar la providencia general que ataje tanto daño y estime justa el Consejo» ${ }^{65}$.

Sus propuestas fueron acogidas favorablemente por el rey y promulgadas en real resolución de 17 de marzo de 1784. Se extinguían las cofradías gremiales y las carentes de aprobación; podían subsistir, en cambio, las cofradías sacramentales y las que gozaban de aprobación eclesiástica y a la vez real, con la condición de renovar sus estatutos ante el Consejo de Castilla; en cuanto a aquéllas que poseían únicamente aprobación eclesiástica se aconsejaba su extinción. La aplicación de estas medidas se reservó a las Audiencias y Chancillerías, y en Madrid a la Sala de Alcaldes de Casa y Corte. En todos los casos, los bienes de las cofradías suprimidas debían pasar a ser administrados por las juntas de caridad.

A pesar de lo radical de la norma, su virtualidad fue bastante limitada. Al parecer, el propio Campomanes aconsejó restringir su aplicación por temor a la reacción popular. Las medidas se ejecutarían sólo contra aquellas hermandades que se vieran envueltas en un proceso judicial. De paso, se limitaba una de las vías más utilizadas por las cofradías para la defensa de sus derechos: el pleito.

La aplicación práctica de las medidas restrictivas en las cofradías españolas fue limitada y desigual. Aunque en algunos lugares como Albacete se suprimieron todas o en otros como Santader se fundieron en una sola hermandad, en ciudades tan importantes por sus cofradías como Sevilla o Valladolid la reducción fue mínima. En todo caso, la aplicación práctica dependió del interés de las autoridades locales en esta materia, en sintonía con la jerarquía eclesiástica.

En los años posteriores, el Consejo de Castilla recordaría la normativa vigente al respecto, insistiendo sobre todo en la necesidad de la aprobación real para la renovación de las reglas de las cofradías. Ello dio lugar a expedientes administrativos muy largos y costosos, y a la afirmación de la competencia de los tribunales de justicia sobre este ámbito de la religiosidad popular.

Lo que no se consiguió aplicando la real resolución de Carlos III se conseguiría, en parte, quince años más tarde a causa de las necesidades económicas del erario público. La situación caótica de la Hacienda en la coyuntura bélica y la imposibilidad de imponer nuevas cargas fiscales a un país fuertemente golpeado por la crisis económica, llevó a pensar en medios más radicales. Un real decreto de 25 de septiembre de 1798, siendo secretario de Hacienda Miguel Cayetano Soler, ordenaba la venta de los bienes raíces pertenecientes a «hospitales, hospicios, casas de misericordia, de reclusión y de expósitos, cofra-

${ }^{65}$ Dictamen de 28 de abril de 1783 (AHN, Consejos, leg. 7090-91, fol. 217). 
días, memorias, obras pías y patronatos de legos ${ }^{66}$. El producto de las ventas pasaría a la Caja de Amortización, de la que estas instituciones recibirían un interés anual del $3 \%$. Con esta medida se aspiraba a obtener fondos y a restablecer el crédito público.

$\mathrm{El}$ ataque a las propiedades de la Iglesia, tan denostadas por los ilustrados, empezó por los bienes para-eclesiásticos, precisamente los de una función social más clara. Los de las cofradías se comprendían entre ellos. Las subastas de estos bienes se intensificaron en los primeros años del siglo XIx. El resultado de esta medida fue la desamortización aproximadamente del $20 \%$ de los bienes eclesiásticos. La reacción del estamento clerical fue bastante tibia. No es posible calcular la participación de las cofradías en este porcentaje, pero, sin duda, fue pequeña. Es obvio que la mayoría de ellas carecían de bienes raíces y se mantenían gracias a las cuotas y donativos de los fieles. Todo parece indicar que aquéllas que poseían bienes raíces vieron muy mermada su capacidad económica. Pero la mayor parte se sostenía con el esfuerzo pecuniario de sus propios miembros.

La invasión napoleónica significó un nuevo ataque a las cofradías. Se continuó la política desamortizadora, dirigida por primera vez a los bienes de las órdenes religiosas, que fueron suprimidas. Esto debió afectar a muchas cofradías y órdenes terceras, ubicadas en conventos ${ }^{67}$. Por tanto, esta medida se hizo notar de forma especial en las ciudades. También se instó a los intendentes a elaborar inventarios de los objetos sagrados y de culto existentes en los templos, como un paso previo para la confiscación de bienes impuesta por una economía de guerra. Todos estos procesos fueron debilitando cada vez más a las cofradías.

Los cambios sociales que tuvieron lugar en España a comienzos de la época contemporánea no hicieron más que acentuar este proceso de decadencia. Ya sujetas a la autoridad civil, mermada su capacidad de gasto y muy afectadas por la crisis económica y demográfica, las cofradías fueron perdiendo su antiguo esplendor y su arraigo popular. En muchos lugares, quedaron convertidas en reducto de los sectores más tradicionales de la sociedad, lo que las hizo objeto de fuertes críticas por parte de los liberales.

Ya entrado el siglo Xix, el número de cofradías en España había disminuido notablemente ${ }^{68}$. La desaparición de los gremios, corporaciones que habían

\footnotetext{
${ }^{66}$ Richard Herr, «Hacia el derrumbe del Antiguo Régimen: crisis fiscal y desamortización bajo Carlos IV», Moneda y crédito, 118 (1971), p. 47.

${ }^{67}$ M. L. López Muñoz, «Control estatal de las asociaciones de laicos...», pág. 357.

${ }^{68}$ Vid. al respectos José Andrés Gallego, «Las cofradías y hermandades en la España Contemporánea», Actas I Congreso Nacional de Cofradías de Semana Santa, Zamora, 1988, págs. 69-75 y Miguel Luis López Muñoz, «Las cofradías en la España del siglo XIX», XX Siglos, VI, 25 (1992-93), págs. 43-56.
} 
dado lugar a numerosas cofradías, la política de disolución de órdenes religiosas, que hizo desaparecer las cofradías con sede en conventos, la desamortización de los bienes eclesiásticos y la pérdida de poder de la Iglesia sobre la sociedad de su tiempo, fueron fenómenos decisivos para la postración de las cofradías. Si a la desaparición de estos pilares se unen los cambios de mentalidad religiosa que trajo consigo el liberalismo, se comprenderá mejor la diferencia abismal entre un siglo XVIII con gran protagonismo de la religiosidad popular y un siglo xIX más laico e indiferente a los moldes de la piedad tradicional.

\section{$X$. Ermitas y romerías}

Muy ligadas al mundo de las cofradías estaban las ermitas y romerías. Las ermitas, pequeñas capillas dedicadas a una advocación titular, estaban muy extendidas por la geografía española. Existían tanto en las ciudades como en el mundo rural (la ciudad de Toledo contaba con más de 20), pero con mayor frecuencia estaban ubicadas en el campo, alejadas de las poblaciones ${ }^{69}$. Casi todos los pueblos y aldeas del país tenían varias ermitas. La inmensa mayoría estaban dedicadas a la Virgen en sus distintas advocaciones, otras a distintos santos, siendo San Sebastián, protector frente a la peste, el santo más popular, aunque no faltaban otras a San Roque, San Bartolomé, etc. ${ }^{70}$.

Algunas servían de sede a cofradías y muchas de ellas tenían una capellanía para su dotación económica. Solían ser lugares de culto no permanente, aunque algunas mejor dotadas podían celebrar actos de culto con mayor asiduidad. Además de los capellanes, que se dedicaban al culto «a tiempo parcial», todas solían tener un «santero», que cuidaba el mantenimiento del recinto sagrado.

Cuando una ermita adquiría especial fama por sus milagros y desbordaba el ámbito de la devoción local, convirtiéndose en un centro de peregrinación, se trataba ya propiamente de un santuario ${ }^{71}$, que representaba una dimensión cualitativamente mayor. La mayoría de ellos habían surgido unidos a leyendas de milagros, apariciones, etc. Con frecuencia se ubicaban en lugares de especial significación en sociedades agrarias, como cerca de fuentes, junto a árboles especialmente portentosos, en parajes de especial belleza, etc. Estos santuarios

\footnotetext{
${ }^{69}$ Es lo que ocurría, por ejemplo, con las abundantes ermitas de la costa de Granada (Miguel Luis López Muñoz, «Ermitas y oratorios en la costa granadina», Anuario de estudios de la costa granadina, 3 (1991), págs. 147-181).

${ }^{70}$ Una síntesis sobre el mundo de las ermitas y santuarios en William A. Christian, Religiosidad local en la España de Felipe II, Madrid, 1991, págs. 93-155.

${ }^{71}$ Juan M Matez Taboada, «La significación de los santuarios», en C. Álvarez Santaló, Ma J. Buxó y S. Rodríguez Becerra, op. cit., vol. III, págs. 268-281.
} 
solían concitar la devoción popular, milagrerías, supersticiones y desviaciones debidas a la ignorancia y a la credulidad. A ellos acudían los fieles buscando auxilio divino a sus problemas, especialmente los de enfermedad, llegó a haber una auténtica especialización de ciertos santos en determinadas enfermedades (Santa Lucía y S. Cristóbal, la vista; S. Sebastián, la peste, S. Mateo la garganta, S. Andrés, las hernias de los niños, etc.) y era frecuente el ofrecimiento de exvotos y otras ofrendas en agradecimiento a este auxilio sobrenatural.

A los santuarios, especialmente marianos, acudían los fieles desde puntos muy distantes, se destinaban cuantiosas limosnas y en ellos el culto se hacía permanente. Los santuarios podían tener una significación regional, nacional e incluso internacional. En España durante el siglo XVIII los santuarios más importantes eran los de Guadalupe, Montserrat, Covadonga, el Pilar. Con frecuencia estaban atendidos por órdenes religiosas.

Ermitas y santuarios contribuían a sacralizar el paisaje y ayudaban a hacer más accesibles las obligaciones de culto a la población dispersa. De todos modos, por su ubicación fuera de las ciudades las autoridades religiosas y locales siempre las consideraron espacios marginales, lugares peligrosos, difíciles de controlar. Las órdenes religiosas tuvieron siempre un gran interés por estos centros de culto.

Escenario de fiestas patronales y romerías, fueron ambas fiestas las que concitaron mayor interés por las autoridades. La fiesta de la ermita solía tener misa con sermón y procesión. En el caso de los santuarios era frecuente que la estancia se prolongara durante varias jornadas, al menos desde la víspera, con gran afluencia de personas y celebración de comidas, bailes, mercados, etc. Estas actividades no estrictamente religiosas son las que despertaban mayor recelo por las autoridades a causa de las posibles alteraciones del orden público y por los excesos morales que podían derivarse del ambiente de libertad, nocturnidad y promiscuidad de sexos que tenían lugar. Téngase en cuenta, por ejemplo que alguna romería, como la de la Virgen de la Cabeza de Andújar ${ }^{72}$, sin duda la más importante romería andaluza de la época, concentraba en el siglo XVIII más de 25.000 personas, procedentes de Andalucía y La Mancha, que después de hacer el camino desde sus respectivas poblaciones vivían en Sierra Morena dos días de continua fiesta el último fin de semana de abril. El obispo de Granada, por ejemplo, clamaba contra las inmoralidades ${ }^{73}$ que se cometían en ella

${ }^{72}$ Enrique Gómez Martínez, «La devoción popular a Nuestra Señora de la Cabeza de Sierra Morena en la Andalucía de los siglos xvi y xviı», en C. Álvarez Santaló, Ma J. Buxó y S. Rodriguez Becerra, op. cit., vol. II, págs. 487-504.

${ }^{73}$ I. Arias de Saavedra y M. L. López Muñoz, Informes de los metropolitanos..., pág. 46. 
y parece que no iba descaminado el prelado, a juzgar por el creciente ritmo de admisiones en la casa cuna de Andújar que se producía nueve meses más tarde.

Las romerías se celebraban por toda la geografía española. En Asturias eran muy abundantes. Jovellanos en sus escritos da gran cantidad de referencias sobre fiestas y romerías asturianas ${ }^{74}$. En Oviedo, por ejemplo, en la ermita de Valesquida los sastres celebraban cabalgadas y regocijos públicos; la romería de $\mathrm{S}$. Blas de Gijón era eminentemente infantil, la del Cristo de Candás celebrada el 14 de septiembre gozaba de gran celebridad. Llama la atención que un ilustrado, como Jovellanos, no se mostrara contrario a estas fiestas y diversiones populares, tan arraigadas en su tierra natal, sino que las considerara una diversión legítima, socialmente conveniente para compensar la dureza de la vida campesina e incluso llegara a considerar a las romerías positivas en el aspecto económico, porque fomentaban el comercio comarcal. Su actitud contrasta vivamente con las prohibiciones de romerías del sínodo diocesano de Oviedo de 1769, celebrado por el obispo Agustín González Pisador, o con la actitud del regente de la Audiencia del principado, Teodomiro Caro de Briones, quien en su informe al Consejo de Castilla en 1771 sugería «que a las ermitas y santuarios que están en despoblados no vayan las gentes a dormir la noche víspera de la función, pues en estas ocasiones con la concurrencia de ambos sexos se experimentan los mayores escándalos y perjuicios» ${ }^{75}$.

No parece que estas quejas cambiaran sustancialmente el panorama de estas fiestas y devociones populares, de modo que en plena guerra napoleónica, ante la persistencia del problema, las Cortes de Cádiz aconsejaban la supresión de las romerías.

A modo de conclusión, cabe hacer una reflexión final sobre la actitud gubernamental respecto a estas manifestaciones de la religiosidad popular. A pesar de la incomprensión y el recelo por parte de las autoridades respecto a estos eventos, tan significativos en el calendario popular y que tanta significación tenían en la vida de las gentes, la actitud represora no fue lo dura y eficaz que podría haberse esperado de un gobierno que sin duda tenía medios para erradicar las manifestaciones más «peligrosas» (desde su punto de vista, naturalmente) de la religiosidad popular. Si esta represión no se produjo totalmente fue, sin duda, por lo incardinada que estaba esta religiosidad popular y sus prácticas en el conjunto de la sociedad. No era aconsejable emprender acciones drásticas contra unas prácticas que tenían tantos adeptos. Lo mismo respecto a las cofradías, como

\footnotetext{
${ }^{74}$ Miguel Luis López MuÑoz, «Una visión ilustrada de la religiosidad popular: Jovellanos», separata de Estudios dieciochistas en homenaje al profesor José Miguel Caso González, Oviedo, 1995, págs. 26-28.

${ }^{75}$ I. Arias de SaAvedra y M. L. López Muñoz, «Intendentes y cofradías en el reinado de Carlos III», pág. 97.
} 
respecto a las ermitas y romerías, la acción de los ilustrados fue más bien de distanciamiento y encauzamiento de las prácticas más llamativas que de frontal represión y aniquilación. Pero no era poco convertir lo general en marginal, lo devoto en fanático, lo sencillo en inculto y lo espontáneo en peligroso. Las cofradías y las manifestaciones de la religiosidad popular se encontraban cada vez más arrinconadas. 